\title{
Coming Inside and/or Playing Outside: The (Legal) Futures of LGBTIQ Rights in the United Kingdom
}

\section{Senthorun Raj and Peter Dunne}

\section{Introduction}

This collection is about making space for queer outsiders, both in UK LGBTIQ law reforms and activist-scholarly discussions of those reforms. To do this, the chapters that we have assembled for this project take the organising concepts of queer, law, inside and outside, and subject them to critical scrutiny. We do not seek to romanticise the terms of queering law or remaining outside the scope of legal recognition, nor are we attempting to reject the possibilities of law reform or the value that comes from being inside the space of legal recognition. The Queer Outside in Law does not resolve the tensions of being queer and inside/outside law. As we noted in the Introduction, citing the work of queer scholars Cynthia Weber, Eve Sedgwick, and Mariana Valverde, the chapters in this collection conceptualise queerness and legality across multiple registers: queerness captures gender and sexual dissidence, both inside and/or outside states and it does not signify dissident genders and sexualities monolithically across different sites of law. ${ }^{1}$ This heterogeneity is how we come to assess LGBTIQ² law reform.

In concluding the collection, we take inspiration from Davina Cooper, who invites us to reconceptualise the State around notions of responsibility and heterogeneity. Cooper notes that pluralising conceptions of "the state" (as a condition of governance) and foregrounding

\footnotetext{
${ }^{1}$ Cynthia Weber, Queer International Relations (Oxford University Press, 2016), p. 16; Eve Sedgwick, Tendencies (Duke University Press, 1993), p. 8; Mariana Valverde, Chronotopes of Law: Jurisdiction, Scale and Governance (Abingdon and New York: Routledge, 2015), p. 66.

${ }^{2}$ In this chapter, we alternate between using "LGBTIQ", "LGBTI", "LGBT", and "LGB" to be precise (without being tokenistic) about the content of statutes, cases, policies, and submissions being discussed.
} 
"playing" (as a provisional and pleasurable strategy of governance) can enable us to realise progressive social agendas. ${ }^{3}$ This lets us - as scholars, activists, and advocates - grasp how diffused legal practices, functioning at different scales, shape state interactions with (and between) subjugated communities. ${ }^{4}$

What is especially timely for us about Cooper's theoretical intervention is how reimagining the state, as an affective set of relations that make public governance possible, enables us to think more carefully about what different modalities of law (legislation, judicial review, street-level decision making) are doing in the process of recognising, protecting and/or punishing LGBTIQ people in the UK. In doing so, we can begin to explore how we might play around with those modalities at grassroots levels to support the lives of those (queer outsiders) who are cast beyond the remit of legal recognition and/or denied social affirmation. Playing, according to Cooper, is a "creative" and "open-ended" strategy that does not seek to make possessive claims about subjects (people, legal issues, state institutions) nor does it require coercive legal sanctions (criminal penalties, economic sanctions). ${ }^{5}$

In this concluding chapter, we take up Cooper's invitation to "play" with(in) the state by exploring four case studies - each of which is at a different stage of development in the United Kingdom. These contemporary examples have been chosen to illustrate how we (as LGBTIQ people) might come inside for rights while also playing outside the law as queer outsiders. The four case studies focus on: (I) self-determination as a means of obtaining legal gender recognition (currently proposed reform); (II) intersex experiences with medicine and rights (subject of a recent Government Equalities Office Call for Information); (III) the

\footnotetext{
${ }^{3}$ Davina Cooper, Feeling Like a State: Desire, Denial, and the Recasting of Authority (Duke University Press, 2019), pp. 24-25.

${ }^{4}$ Ibid, p. 55.

${ }^{5}$ Ibid, p. 116.
} 
adjudication of LGBT asylum claims (under Home Office review): and (IV) LGBT-inclusive relationships and sex education in schools (policy to be implemented in England no later than the start of the summer term 2021). ${ }^{6}$ Taken together, the case studies reflect the myriad legal, cultural and political challenges which confront queer populations in modern UK society. They interrogate key questions posed by the various chapters in this edited collection and invite the reader to think more broadly about the complexities of LGBTIQ| law reform. In exploring these four case studies, we are: (a) drawing both from and together the core themes and insights identified by those who have contributed to this book; and (a) seeking to locate current and proposed LGBTIQ laws within existing discourses on rights, identity and effective social movement building. Ultimately, we address our discussions and concluding remarks to three fundamental questions that we hope will be the subjects of further socio-legal work: (I) why do LGBTIQ people seek to come inside law? (II) what has happened to LGBTIQ people who have come inside the law? and (III) what can be gained from staying or playing outside?

\section{Case Study I. Defining Identity:}

\section{Autonomy, Control and the Gender Recognition Act 2004}

"...it is humiliating to have your gender assessed by someone else. You are the only person who can come to that realisation, not a panel...I do not feel it necessary to have my gender looked at by a group of people."7

Since April 2005, individuals in the United Kingdom have been able to access formal acknowledgment of their self-identified gender. ${ }^{8}$ Under the terms of the Gender Recognition

\footnotetext{
${ }^{6}$ Department of Education, Communication to schools on the implementation of Relationships Education, Relationships and Sex and Health Education, p. 1 (June 2020).

${ }^{7}$ House of Commons Select Committee on Women and Equalities, Transgender Equality (London: The Stationery Office Limited, 2016), [41] per Ashley Reed.

${ }^{8}$ Peter Dunne, "Ten years of gender recognition in the United Kingdom: still a "model for reform"?" Public Law Oct. (2015): 530-539; Alex Sharpe, "Endless Sex: The Gender Recognition Act 2004 and the Persistence of a Legal Category" Feminist Legal Studies 15 (1) (2007): 57-84; Stephen Whittle, "The Opposite of Sex is Politics-The UK Gender Recognition Act and Why it is Not Perfect, Just Like You and Me: FORUM." Journal of Gender Studies 15 (3) (2006): 267-271; Emily Grabham, "Governing Permanence: Trans Subjects, Time,
} 
Act 2004 (GRA 2004), where an applicant successfully obtains a Gender Recognition

Certificate (GRC), that “person's gender becomes for all purposes the acquired ${ }^{9}$ gender (so that, if the acquired gender is the male gender, the person's [legal] sex becomes that of a man and, if it is the female gender, the person's [legal] sex becomes that of a woman)." ${ }^{10}$ As Flora Renz notes in Chapter 6, the GRA 2004 was a landmark moment for human rights - both in this jurisdiction and across Europe. In England and Wales, the legislation represented an explicit, statutory repudiation of the (in)famous Corbett $^{11}$ case law ${ }^{12}-$ under which trans persons had been denied validation of their lived identity. For Europe, and farther afield, the Gender Recognition Act 2004 stood as a key point of departure - a national framework, which showed that self-identified gender could be acknowledged without requiring an applicant to undertake a process of sterilisation. ${ }^{13}$

\footnotetext{
And The Gender Recognition Act" Social \& Legal Studies 19(1) (2010): 107-126: Ralph Sandland, "Feminism and the Gender Recognition Act 2004" Feminist Legal Studies 13(1) (2005): 43-66.

${ }^{9}$ Section 1(2) of the Gender Recognition Act 2004 states that, "[i]n this Act 'the acquired gender', in relation to a person by whom an application under subsection (1) is or has been made, means - (a) in the case of an application under paragraph (a) of that subsection, the gender in which the person is living, or (b) in the case of an application under paragraph (b) of that subsection, the gender to which the person has changed under the law of the country or territory concerned." Thus, when referring to a person's self-identified gender (as opposed to their Birth Assigned Gender), the GRA 2004 specifically speaks of a person's "acquired gender". It is important to acknowledge that there is no universally preferred terminology when referring to gender, and that many individuals may find the idea of an "acquired" gender (i.e. an identity which the Gender Recognition Act 2004 creates, but which has no prior existence) as both offensive and as inconsistent with their lived experience. ${ }^{10}$ Gender Recognition Act 2004, s. 9(1). It is important to note that sub-sections 9(2) and (3) qualify the general right set out in s. 9(1) of the GRA 2004. Section 9(2) provides that "[s]ubsection (1) does not affect things done, or events occurring, before the certificate is issued; but it does operate for the interpretation of enactments passed, and instruments and other documents made, before the certificate is issued (as well as those passed or made afterwards)." Furthermore, according to s. 9(3), "[s]ubsection (1) is subject to provision made by this Act or any other enactment or any subordinate legislation."

${ }^{11}$ Corbett v Corbett (Otherwise Ashley) (No 1) [1971] 2 All ER 33.

${ }^{12}$ See: Sharon Cowan, "That Woman Is a Woman!" the Case of Bellinger v. Bellinger and the Mysterious (Dis) appearance of Sex: Bellinger v. Bellinger [2003] 2 All ER 593;[2003] FCR 1; [2003] 2 WLR 1174; [2003] UKHL 21" Feminist Legal Studies 12 (1) (2004): 79-92; Anne Barlow, "A new approach to transsexualism and a missed opportunity?" Child and Family Law Quarterly 13(2) (2001): 225-240; Stephen Gilmore, "Bellinger v Bellinger - not quite between the ears and between the legs - transsexualism and marriage in the Lords" Child and Family Law Quarterly 15(3) (2003): 295-311.

${ }^{13}$ For a comparative discussion of the legal gender recognition laws post-2004, see: Jens M Scherpe (ed), The Legal Status of Transsexual and Transgender Persons (Intersentia, 2015). In particular, see: Jens M Scherpe and Peter Dunne, "The Legal Recognition of Transsexual and Transgender Persons - Comparative Analysis and Recommendations" in that collection.
} 
In the years preceding the GRA 2004, there had been an increasing domestic campaign advocating for gender recognition rights in the United Kingdom. ${ }^{14}$ Although scholars, such as Gonzalez-Salzberg have noted the queer potential of trans populations playing outside the realms of formal acknowledgment - particularly where, as the in UK, individuals often had diverging genders on multiple, state-issued documents ${ }^{15}$, a strong catalyst for change emerged with the historic judgment of the European Court of Human Rights (ECtHR), Goodwin v United Kingdom. ${ }^{16}$ In its decision, the ECtHR found that withholding official validation of selfidentified gender (at least for individuals who had undertaken a process of surgical transition) was incompatible with art. 8 of the European Convention of Human Rights (ECHR). ${ }^{17}$

The Goodwin litigation brought into sharp relief the many reasons why trans and nonbinary individuals might seek acknowledgement of their lived identity and why an existence "outside" the sphere of legal recognition can be experienced as a dignitary injury. The absence of legal validation means that, as in Goodwin, trans and non-binary individuals are frequently denied key benefits (e.g. social advantages, social protection, etc.). ${ }^{18}$ Ms Goodwin, for

\footnotetext{
${ }^{14}$ Evelyn Ellis, “The Gender Recognition Bill” Public Law Autumn (2004): 467-471, who notes, when speaking about the GRA 2004 (when in Bill form) [at pp. 467- 468] that "[t]he Bill, which had Government backing, was introduced into the House of Lords. It received the approval of the Commons at a Second Reading in February this year, and completed its Commons Committee stage in mid-March. It is a detailed and carefully crafted instrument whose subject-matter was first considered by an Interdepartmental Working Group in 1999" (emphasis added). See, in particular, the important campaigning work of the organization, Press for Change, during the 1990s and the early 2000s: Press for Change website, accessed March 28, 2020, http://www.pfc.org.uk.

${ }^{15}$ Damian A Gonzalez-Salzberg, "The Accepted Transsexual and the Absent Transgender: A Queer Reading of the Regulation of Sex/Gender by the European Court of Human Rights" American University International Law Review 29(4) (2013): 797, 810-811, 814.

${ }^{16}$ [2002] 35 EHRR 18.

17 Ibid, [93].

${ }^{18}$ In Goodwin, the European Court of Human Rights observed, at para. 76, that withholding gender recognition "has had, and continues to have, effects on the applicant's life where sex is of legal relevance and distinctions are made between men and women, as, inter alia, in the area of pensions and retirement age. For example, the applicant must continue to pay national insurance contributions until the age of 65 due to her legal status as male. However as she is employed in her gender identity as a female, she has had to obtain an exemption certificate which allows the payments from her employer to stop while she continues to make such payments herself. Though the Government submitted that this made due allowance for the difficulties of her position, the Court would note that she nonetheless has to make use of a special procedure that might in itself call attention to her status."
} 
example, could not enter into a marriage with a male partner because English law deemed that she was legally male, and it did not yet sanction same-sex marital unions. ${ }^{19}$

Refusing to acknowledge self-identified gender may also expose individuals both to allegations of fraud and to heightened levels of abuse. Where trans and non-binary persons lack legal recognition, which is congruent with their public expression of identity, they are frequently subject to social and institutional gender questioning, including accusations that they are misrepresenting their identity for self-gain. ${ }^{20}$ This lived reality can substantially limit trans and non-binary access to basic services, such as transportation, education, healthcare and the domestic postal system. ${ }^{21}$ In addition, these conflicts between public expressions of gender and legal status may also increase risks of discrimination and violence. Where incongruence exists between self-identified and legal gender, there is a greater likelihood that an individual's trans history will be publicly revealed and that this person may experience the consequences of transphobia. $^{22}$

Finally, for many individuals - although acutely aware of the practical impact of withholding formal acknowledgment - their primary focus in advocating for gender recognition is the symbolic injury, which they experience as a result of legal exclusion. Where jurisdictions, such as the United Kingdom, refuse to validate self-identified gender, this

\footnotetext{
${ }^{19}$ Ibid, [94] - [104].

${ }^{20}$ Michael Silverman, “Issues in Access to Healthcare by Transgender Individuals” Women's Rights Law Reporter 30(2) (2009): 347, 349; Jordan Aikan, "Promoting an Integrated Approach to Ensuring Access to Gender Incongruent Health Care" Berkeley Journal of Gender, Law and Justice 31(1) (2016): 1, 33.

${ }^{21}$ Report of the Independent Expert on protection against violence and discrimination based on sexual orientation and gender identity (May 12, 2018) UN Doc No. A/HRC/38/43, [43], where the Independent Expert observes that "[i]naccurate or inadequate identity documents may result in greater levels of violence and extortion, exclusion from school and the official labour market, housing, health... and access to other social services, and in being able to cross borders" (emphasis added).

${ }^{22}$ Ibid, [43], where the Independent Expert notes that "[ $\left.\mathrm{t}\right] \mathrm{rans}$ persons are particularly vulnerable to human rights violations when their name and sex details in official documents do not match their gender identity or expression."
} 
implicitly undermines trans identities and legitimatises unequal treatment motivated by disrespect for trans personhood. ${ }^{23}$ Of course, subjecting such argument to a queer lens of analysis, one might question, as Renz suggests, why the value and legitimacy of gender should depend either upon state approval or on an individual coming within prescribed narratives of acceptable gender. There is at least a plausible argument that, by seeking to come inside inherently defective structures of identity regulation, queer individuals will only reinforce the very gender institutionalism, which is the source of their oppression. From this perspective, there may be greater merit in queers choosing to play outside the scope of legal recognition, working creatively to radically reshape how law, gender and the state interact. Yet, what symbolism-focused concerns do reveal is that, within a context where social and legal privilege are still contingent upon status, many trans and non-binary individuals experience both tangible and intangible disadvantage when excluded from official acknowledgment.

The Gender Recognition Act 2004 was an attempt to address the problems (both practical and symbolic) created by the legal invisibility of trans populations in the UK. It established a framework for acknowledging trans identities - centred around core supervisory pillars, including the required invention of specialist medical officers, the oversight of a Gender Recognition Panel and an obligation to live in one's self-identified gender for two years before applying. ${ }^{24}$ Although the GRA 2004 was broadly welcomed as a milestone in domestic human rights protections, it was also subject to critique. ${ }^{25}$ In 2016, the Commons Select Committee on Women and Equalities recommended fundamental changes to the existing statutory

\footnotetext{
${ }^{23}$ In Goodwin, Christine Goodwin argued that "[t]he lack of legal recognition of her changed gender had been the cause of numerous discriminatory and humiliating experiences in her everyday life", [2002] 35 EHRR 18, [60].

${ }^{24}$ Gender Recognition Act 2004, s. 2(1).

${ }^{25}$ Peter Dunne, "Ten years of gender recognition in the United Kingdom: still a "model for reform"?" Public Law Oct. (2015): 530-539; Alex Sharpe, "Gender Recognition in the UK: A Great Leap Forward." Social \& Legal Studies 18 (2) (2009): 241-245, 244-245.
} 
regime ${ }^{26}$ and the Government Equalities Office subsequently issued a public consultation on reform (still under analysis at the time of writing). ${ }^{27}$ In 2019, the Scottish Government went one step further, seeking public comments on a draft amending bill, the Gender Recognition Reform (Scotland) Bill. ${ }^{28}$

There are a number of objections which have been raised against the Gender Recognition Act 2004. While the legislation was striking for the absence of a sterilisation requirement (common in other European laws at the time), it remains a fundamentally medicalised framework. In order to obtain a Gender Recognition Certificate, applicants must show that they have, or have had, a diagnosis of "gender dysphoria" - requiring verification from at least two medical practitioners or psychologists. ${ }^{29}$ This "diagnosis requirement", as it has come to be known, is strongly opposed by many trans individuals and their allies. ${ }^{30}$ Mandating a diagnosis assumes that all trans individuals see their gender identity in medical terms $\mathrm{s}^{31}$ and that all applicants for gender recognition will feel distress related to their internal experience of gender. This is not only untrue for many applicants (who may be comfortable with their gender identity and, thus, possibly excluded from a diagnosis of gender dysphoria);

\footnotetext{
${ }^{26}$ House of Commons Select Committee on Women and Equalities, Transgender Equality (London: The Stationery Office Limited, 2016), [44]-[45], [70]-[71].

27 "Reform of the Gender Recognition Act 2004" UK Government website, July 3, 2018, accessed March 29, 2020, https://www.gov.uk/government/consultations/reform-of-the-gender-recognition-act-2004.

28 "Gender Recognition Reform (Scotland) Bill: consultation" Scottish Government website, December 17, 2019, accessed March 29, 2020, https://www.gov.scot/publications/gender-recognition-reform-scotland-bill-consultation-scottishgovernment.

${ }^{29}$ Gender Recognition Act 2004, s. 2(1) and s. 3.

30 The House of Commons Select Committee on Women and Equalities observed that "[t]he current process of applying for a GRC was described to us as bureaucratic', 'expensive' and 'humiliating'. Witnesses told us that it required the collection and submission of substantial quantities of evidence of a type which ought to have no bearing on the granting of gender recognition.", House of Commons Select Committee on Women and Equalities, Transgender Equality (London: The Stationery Office Limited, 2016), [33].

${ }^{31}$ This is a general phenomenon that many scholars, across jurisdictions, have noted -in relation to physical and mental health gender affirmative care. See e.g. Sana Loue, "Transsexualism in medicolegal limine: an examination and a proposal for change" Journal of Psychiatry and Law 24(1) (1996): 27, 34; Dean Spade, "Documenting Gender" Hastings L.J. 59 (2007): 731, 756.
} 
it also reproduces an historic trope that trans identities are pathological. ${ }^{32}$ Rather than upholding a core human right, access to a Gender Recognition Certificate would be seen as merely one element in a wider protocol for curing trans populations. ${ }^{33}$ While seeking to avoid ableist norms, which frame mental health as inevitably stigmatised, ${ }^{34}$ linking the GRA 2004 to requirements of diagnosis encourages cultural perceptions of trans individuals as confused, incapable and needing protection.

The current structures of the Gender Recognition Act 2004 are also highly exclusionary - failing to acknowledge (either explicitly or implicitly) core demographics ${ }^{35}$. In order to come within the statutory framework, an applicant must have achieved the age of majority. ${ }^{36} \mathrm{At}$ present, it is not possible for children or adolescents, under 18 years, to apply for a Gender Recognition Certificate. In recent times, the status, and appropriate response to, trans and nonbinary youth, both in law and in medicine, has become a source of political, media and social

\footnotetext{
32 Jens M Scherpe and Peter Dunne, "The Legal Recognition of Transsexual and Transgender Persons Comparative Analysis and Recommendations" in Jens M Scherpe (ed), The Legal Status of Transsexual and Transgender Persons (Intersentia, 2015), pp. 653-654. Pieter Canoot writes that it is "striking that the Court continues to allow the requirement of providing evidence of the existence of the 'syndrome of transsexuality', sex reassignment therapy, and the possibility for the State to order the performance of a medical expert examination, considering its recognition that the psycho-pathologisation of gender identity reinforces stigmatization of trans* persons", see: Pieter Canoot, "The pathologisation of trans* persons in the ECtHR's case law on legal gender recognition" Netherlands Quarterly of Human Rights 37(1) (2019): 14-35, 23. ${ }^{33}$ Ibid.

${ }^{34}$ Dean Spade, "Resisting Medicine, Re/modelling Gender” Berkeley Women's Law Journal 18 (2003): 15, 34.

${ }^{35}$ House of Commons Select Committee on Women and Equalities, Transgender Equality (London: The Stationery Office Limited, 2016), [31] and [64]-[71].

${ }^{36}$ Gender Recognition Act 2004, s. 1(1). See: Peter Dunne, "Transgender Children and the Law" Family Law 47 (January) (2017): 123-124.
} 
debate. ${ }^{37}$ Among those who oppose affirmative interventions ${ }^{38}$, there is concern that trans youth are insufficiently mature to understand the full complexity of their identity ${ }^{39}$, and there are increasing claims that patriarchal social norms pressure young cisgender girls to transition. ${ }^{40}$ Opposition to trans affirmation has manifested itself in high-profile campaigns to maintain age restrictions in the GRA $2004^{41}$ and a judicial review seeking to limit access to reversible, puberty blocking medication. ${ }^{42}$

Much of the disagreement surrounding trans and non-binary youth stems from a comparative lack of medical and social research. There are legitimate questions as to whether

\footnotetext{
${ }^{37}$ Janice Turner, "Cult of Gender Identity is Harming Children" The Sunday Times, September 21, 2019, accessed March 29, 2020, https://www.thetimes.co.uk/article/cult-of-gender-identity-is-harming-childrenpjvbkjzxq; Leyla Sanai, "The Danger of Letting Children Transition Too Early” The Spectator, May 13, 2019, accessed March 29, 2020, https://www.spectator.co.uk/article/the-danger-of-letting-children-transition-gendertoo-early; Vic Parsons, "Trans kids are as sure of their gender as cis kids at a young age, according to science" Pink News, December 27, 2019, accessed March 29, 2020,

https://www.pinknews.co.uk/2019/12/27/transgender-children-study-gender-identity-cis-children-washingtonuniversity/; Julian Norman, “'Shifting Sands' Six Legal Views on the Transgender Debate” The Guardian, October 19, 2018, accessed March 29, 2020, https://www.theguardian.com/society/2018/oct/19/genderrecognition-act-reforms-six-legal-views-transgender-debate.

${ }^{38}$ See e.g. Heather Brunskell-Evans, "The Medico-Legal 'Making' of the Transgender Child" Medical Law Review 27(4) (2019): 640-657.

${ }^{39}$ Keira Bell, who is acting as an applicant in a judicial review of the gender affirmative care protocols adopted by the NHS Gender Identity Development Service (Gids), located within the Tavistock and Portman NHS Trust, states that: "I have become a claimant in this case because I do not believe that children and young people can consent to the use of powerful and experimental hormone drugs like I did. I believe that the current affirmative system put in place by the Tavistock is inadequate as it does not allow for exploration of these gender dysphoric feelings nor does it seek to find the underlying causes of this condition. Hormone changing drugs and surgery does not work for everyone and it certainly should not be offered to someone under the age of 18 when they are emotionally and mentally vulnerable. The treatment urgently needs to change so that it does not put young people, like me, on a torturous and unnecessary path that is permanent and life changing." Mrs A, who is also an applicant in the judicial review, states: "I have deep concerns that the current clinical approach at GIDS means that my daughter will be subjected to an experimental treatment path that is not adequately regulated, where there are insufficient safeguards, where her autism will not be properly accounted for and where no-one (let alone my daughter) understands the risks and therefore cannot ensure informed consent is obtained." See: "LEGAL CASE TO PROTECT CHILDREN FROM EXPERIMENTAL MEDICAL TREATMENT" Crowd Justice, accessed March 29, 2020, https://www.crowdjustice.com/case/protect-children/.

${ }^{40}$ Emma Hartley, "Why do so many teenage girls want to change gender?" Prospect, March 3, 2020, accessed March 29, 2020, https://www.prospectmagazine.co.uk/magazine/tavistock-transgender-transition-teenage-girlsfemale-to-male.

${ }^{41}$ For example, Transgender Trend is a UK-based organisation, which has recently emerged as an opponent of reforms to the GRA 2004. Here is their recent submission on the Gender Recognition Reform (Scotland) Bill; Transgender Trend, "Transgender Trend Submission to the Gender Recognition Reform (Scotland) Bill Consultation", March 21, 2020, accessed March 29, 2020, https://www.transgendertrend.com/transgender-trendsubmission-gender-recognition-reform-scotland-bill/.

${ }^{42} R($ ota $)$ Mrs A, and Sue Evans v. Tavistock and Portman NHS Foundation Trust (due for full hearing in the summer 2020).
} 
young individuals, who were previously identified as trans, ultimately persist with that identification into adulthood. ${ }^{43}$ Yet, there are equally question marks relating to the present data on persistence/desistence ${ }^{44}$, and an increasing body of scholarship indicates the benefits of affirmation. ${ }^{45}$ Furthermore, it is also unclear where one can locate the voice of transgender children and adolescents within this ongoing political and social discussions. If a queer approach to law is one, which centres lived or subjective experiences, is it not troubling that contemporary dialogue on these issues, particularly arguments which oppose positive interventions, frequently omit the perspectives of trans and non-binary youth?

A preferable approach would be to adopt a case-by-case analysis, centred on the particular needs and development of individual children. ${ }^{46}$ While legal gender recognition will not be appropriate for many persons under 18 years, the law must be responsive to, and accommodate, those children for whom a GRC would be beneficial. A queer lens on gender recognition would also, as Sharon Cowan encourages in Chapter 8 , accurately disaggregate the various modes of transition which individuals can choose - understanding that different factors are relevant where a minor considers medical and legal transition pathways, and

\footnotetext{
${ }^{43}$ Herbert J Bonifacio and Stephen M Rosenthal, "Gender Variance and Dysphoria in Children and Adolescents" Paediatric Clinics of North America 62(4) (2015): 1001, 1004; Stephen Rosenthal, "Approach to the Patient: Transgender Youth: Endocrine Considerations" The Journal of Clinical Endocrinology and Metabolism 99(12) (2014): 4379, 4384.

${ }^{44}$ Kristina Olson, 'Prepubescent Transgender Children: What We Know and What we Do Not Know' (2016) 55(3) Journal of the American Academy of Child and Adolescent Psychiatry 155, 155; "Statement on Gender Affirmative Approach to Care from the Paediatric Endocrine Society Special Interest Group on Transgender Health", accessed March 29, 2020, https://www.pedsendo.org/members/members_only/PDF/TG_SIG_Position\%20Statement_10_20_16.pdf; Randall D Ehrbar et al, "Clinician Judgment in the Diagnosis of Gender Identity Disorder in Children" Journal of Sex and Marital Therapy 34(5) (2008): 385, 388; Brynn Tannehill, "The End of the Desistence Myth", Huffington Post, January 1 2016, accessed March 29, 2020, http://www.huffingtonpost.com/brynn-tannehill/theend-of-the-desistance_b_8903690.html.

${ }^{45}$ Annelou de Vries et al, "Young Adult Psychological Outcome After Puberty Suppression and Gender Reassignment" Paediatrics 134(4) (2014): 696; Kristina R Olson et al, "Mental Health of Transgender Children Who Are Supported in Their Identities" Paediatrics 137(3) (2016).

${ }^{46}$ Such an approach appears to be possible in a number of other European jurisdictions, such as Malta, Norway and Ireland (although Ireland and Norway do have lower age limits under which a child cannot be formally acknowledged in their self-identified gender) see: Peter Dunne and Marjolein van den Brink, Trans and Intersex Equality Rights in Europe: A Comparative Analysis (Luxembourg: Publications Office of the European Union, 2018), pp. 65-66.
} 
acknowledging that conflating these separate choices obstructs, rather than promotes, the welfare of the child.

The Gender Recognition Act 2004 also excludes non-binary individuals. Section 1 of the GRA 2004 speaks of a person of "either" gender who has been "living in the other gender". The current statutory framework clearly envisages only requests where an applicant, who is either male or female, wishes to legally transition to another binary gender option. For those who do not fit within traditional gender classifications, and who do not self-identify as either "man" or "woman", the GRA 2004 fails to accommodate for their lived experiences, nor are there other identity documents (e.g. passport, etc. ${ }^{47}$ which would accurately reflect their internal understandings of gender.

The current UK position largely conforms to peer gender recognition structures across Europe. ${ }^{48}$ Although, as Renz observes, there are a small number of European jurisdictions, such as Germany and Austria, which provide for alternative legal gender options, these countries largely restrict non-binary recognition to persons who experience intersex variance. ${ }^{49}$ In their contribution, Fae Garland and Mitchell Travis critique such restrictions - observing how they mispresent intersex experiences of gender, while simultaneously excluding vast numbers of non-binary individuals.

Although the Gender Recognition Act 2004 mirrors European practice, it is inconsistent with recent results from the Government's National LGBT Survey - which reveal that a

\footnotetext{
${ }^{47}$ Elan-Cane v Home Secretary [2020] EWCA Civ 363.

${ }^{48}$ Peter Dunne and Marjolein van den Brink, Trans and Intersex Equality Rights in Europe: A Comparative Analysis (Luxembourg: Publications Office of the European Union, 2018), pp. 66-67.

${ }^{49}$ Peter Dunne, "Acknowledging or Erasing Intersex Experiences? Gender 'Diversity' in German Law" Northern Ireland Legal Quarterly 70(1) (2019): 163-169.
} 
growing number of queer persons in the UK self-identify beyond male or female. ${ }^{50}$ For these individuals, the GRA 2004 presents a stark decision: continue to inhabit an incorrect identity status involuntarily assigned to you at birth, or embrace an alternative gender classification, which inaccurately reflects your internal understanding of self. As the facts in $R$ (on the application of Christie Elan-Cane) and Secretary of State for the Home Department lay bare, such impossible choices place significant practical and emotional burdens upon non-binary populations. ${ }^{51}$ A queer approach to law reform would acknowledge this dignitary injury and, even within the constraints of a binary legal system, seek to validate the multiple ways in which individuals experience gender, even if through alternative recognition procedures ${ }^{52}$ (such as the issue of " $\mathrm{X}$ " passports, as requested in the Elan-Cane litigation ${ }^{53}$ ).

In light of the current defects within the Gender Recognition Act 2004, what might a queer reform agenda look like for this area of law? Even if we choose to validate state regulation of gender identity, are there ways that we, as queers, can playfully work, inside the gender recognition frameworks, to redesign how such regulation operates?

In an increasing number of European jurisdictions, including Ireland, Portugal and Belgium, legislatures are adopting affirmation models grounded in the principle of self-

\footnotetext{
${ }^{50}$ Government Equalities Office, National LGBT Survey: Summary Report (June 2018), p. 8, accessed March 29, 2020, https://assets.publishing.service.gov.uk/government/uploads/system/uploads/attachment_data/file/722314/GEOLGBT-Survey-Report.pdf.

${ }^{51}$ Elan-Cane v Home Secretary [2020] EWCA Civ 363 (Court of Appeal Decision); [2018] EWHC 1530 (Admin) (High Court Decision).

${ }^{52}$ See: House of Commons Select Committee on Women and Equalities, Transgender Equality (London: The Stationery Office Limited, 2016) where the Committee recommends, at [299], that "[t]he Government should be moving towards 'non-gendering' official records as a general principle and only recording gender where it is a relevant piece of information. Where information on gender is required for monitoring purposes, it should be recorded separately from individuals' personal records and only subject to the consent of those concerned." ${ }^{53}$ The option of an "X" passport is available in Malta, see: Peter Dunne and Stephen Clark, Comparative Legal Overview of Gender Recognition Laws across the Commonwealth (Equality and Justice Alliance, 2019), p. 40.
} 
determination. ${ }^{54}$ This means that individuals are entitled to access official validation based upon their own personal experience of gender rather than on compliance with externally imposed pre-conditions. ${ }^{55}$ For many trans individuals, self-determination is a preferable system of recognition, acknowledging that applicants themselves, rather than state-appointed third parties, should be the arbiter of personal gender. While many trans and non-binary persons are anxious that they should still have appropriate access to medical transition pathways, ${ }^{56}$ selfdetermination does remove the obligation to comply with the stigmatizing, often inaccessible diagnosis requirements, which some believe should not form part of legal structures.

In this jurisdiction, both the UK and Scottish governments have mooted the possible introduction of self-determination. ${ }^{57}$ However, these proposals have been criticised as compromising the rights and safety of cisgender woman - with the strongest critiques often originating from "gender-critical" individuals. ${ }^{58}$ While any queer reform project should be sensitive (and attentive) to the ways in which law reproduces systemic, gender-based violence, opposition to self-determination in the UK relies upon a number of questionable assumptions. To the extent that observers fear that self-determination will aid cisgender men to fraudulently access single-sex spaces, this misunderstands the relationship between the GRA 2004 and the

\footnotetext{
${ }^{54}$ Peter Dunne and Marjolein van den Brink, Trans and Intersex Equality Rights in Europe: A Comparative Analysis (Luxembourg: Publications Office of the European Union, 2018), pp. 59.

${ }^{55}$ Pieter Cannoot offers an interesting discussion relating to self-determination in "The pathologisation of trans* persons in the ECtHR's case law on legal gender recognition" Netherlands Quarterly of Human Rights 37(1) (2019): 14-35. Jens T. Theilen has also discussed the depathologisation of legal gender recognition in "Depathologisation of Transgenderism and International Human Rights Law" Human Rights Law Review 14 (2014): 327-342.

${ }^{56}$ Chris Dietz, "Governing Legal Embodiment: On the Limits of Self-Declaration" Feminist Legal Studies 26 (2018): 185-204.

${ }^{57}$ Gender Recognition Reform (Scotland) Bill: consultation” Scottish Government website, December 17, 2019, accessed March 29, 2020, https:/www.gov.scot/publications/gender-recognition-reform-scotland-bill-consultation-scottishgovernment/; "Reform of the Gender Recognition Act 2004" UK Government website, July 3, 2018, accessed March 29, 2020, https://www.gov.uk/government/consultations/reform-of-the-gender-recognition-act-2004. ${ }^{58}$ See e.g. Kathleen Stock, "Why Self-Identification Should not Legally Make You a Woman" The Conversation, October 1, 2018, accessed March 29, 2020, https://theconversation.com/why-self-identificationshould-not-legally-make-you-a-woman-103372.
} 
Equality Act 2010. ${ }^{59}$ More fundamentally, as Cowan observes in this collection, it suggests, that the rights of trans individuals in the UK should be contingent upon the behaviour of cisgender peers (a standard not applied to any other protected group). Rather, a preferable, queer approach to legal recognition would be one, which acknowledges the multifarious ways in which gender-based oppression impacts all individuals; this would allow us to heed Cooper's call, to creatively re-reimagine how we validate gender, while working in coalition to counteract all discrimination, violence and abuse, which arises from repressive gender norms. ${ }^{60}$

A queer approach to law might also look beyond gender recognition. As noted, there are cogent arguments for questioning the confirmatory powers which we locate (both explicitly and implicitly) within state validation, and to explore the emancipatory potential of playing outside state-sanctioned gendered borders. Can a system - however accessible - which conditions the legitimacy of gender upon state approval ever be anything other than disempowering for trans and non-binary populations? Perhaps, rather than seeking to improve legal recognition frameworks, a queerer methodology would interrogate the necessity of legal gender or seek to reimagine the role which gender plays within the law.

Even for those who are reticent about the potential of a de-gendered legal system (and there are compelling reasons to adopt such position ${ }^{61}$ ), it is not clear that legal gender recognition is actually an optimal strategy for incorporating trans and non-binary experiences into UK laws. As Renz and Cowan's contributions illustrate, legal approaches to gender recognition, both in this jurisdiction and across Europe, typically emphasise the private aspects

\footnotetext{
${ }^{59}$ Alex Sharpe, "Will Gender Self-Declaration Undermine Women's Rights and Lead to an Increase in Harms?" Modern Law Review, accessed March 24, 2020. https://doi.org/10.1111/1468-2230.12507.

${ }^{60}$ Davina Cooper, “A Very Binary Drama: The Conceptual Struggle for Gender's Future”feminists@law 9(1) (2019): 1-36.

${ }^{61}$ Peter Dunne and Jule Mulder, "Beyond the Binary: Towards a Third Sex Category in Germany?" German Law Journal 19(3) (2018): 627-648, 645-646.
} 
of gender identity - foregrounding personal entitlements to develop one's identity without interference. There has been, however, less substantive consideration of the public dimensions of gender, or of how state policy towards gender creates (or enshrines) systemic discrimination. ${ }^{62}$ In the United Kingdom, greater focus on equality-based remedies, including a movement towards "gender identity" (rather than "gender reassignment") ${ }^{63}$ and an expanded understanding of reasonable accommodation, might ultimately have a greater impact in enhancing the well-being and lived experiences of trans populations.

\title{
Case Study II. Intersex in the UK:
}

\section{Invisibility, Bodily Integrity and Owning How You Come "Inside"}

\begin{abstract}
“...In essence, as a result of surgeries or other sex-altering medical interventions, intersex people are denied their right to physical integrity as well as their ability to develop their own gender identity, as an a priori choice is made for them. Additionally, these interventions often disrupt their physical and psychological well-being, producing negative impacts with lifelong consequences, which include sterilisation, severe scarring, infections in the urinary tract, reduced or complete loss of sexual sensation, removal of natural hormones, dependency on medication, and a deep feeling of violation of their person..." 64
\end{abstract}

On January 17, 2019, the Government Equalities Office (GEO) launched a "call for information", seeking to provide "everyone in the United Kingdom, especially people with variations in sex characteristics, with an opportunity to engage with Government and to tell us

\footnotetext{
${ }^{62}$ See e.g. Iina Sofia Korkiamäki, "Legal Gender Recognition and (Lack of) Equality in the European Court of Human Rights" The Equal Rights Review 13 (2014): 20-50.

${ }^{63}$ Peter Dunne and Marjolein van den Brink, Trans and Intersex Equality Rights in Europe: A Comparative Analysis (Luxembourg: Publications Office of the European Union, 2018), pp. 46-47, where the authors talk about the potential benefit of the language of "gender identity" rather than relying upon "sex" or "gender reassignment". Under s. 7 of the Equality Act 2010, "gender reassignment" is currently the specific protected characteristic in UK law. This reflects EU case law, such as $P v S$ and Cornwall Case C-13/94 [1996] ECR I2143 , and secondary legislation, such as Directive 2006/54.

${ }^{64}$ Council of Europe Commissioner for Human Rights, Human Rights and Intersex (Council of Europe, 2015). 14.
} 
in detail about their experiences." ${ }^{65}$ The announcement - which controversially used the term, "variations in sex characteristics" rather than "intersex" - did not seek feedback on a specific policy or proposal; rather, it commenced an "information gathering process" where a range of relevant stakeholders, including those who experience intersex, could securely and confidentially communicate their insights and perspectives to policy makers. ${ }^{66}$

As Garland and Travis note in Chapter 7, "intersex" is an umbrella term that refers to individuals who are born with chromosomal, hormonal or genital variations in sex characteristics that mean they fall outside of commonplace understandings of male or female. In recent years, both within activist dialogue and human rights adjudication, experiences of intersex have been increasingly (but not unproblematically ${ }^{67}$ ) linked with wider political debates on sexual orientation and gender identity. ${ }^{68}$ The acronym "LGBTQ" has expanded to embrace gay, lesbian, bisexual, trans, intersex and queer populations, and key civil society organisations have reframed their advocacy work to encompass sex characteristics. ${ }^{69}$ Yet, in many ways, the GEO's call for information - rather than evidence of a logical step in a unidirectional arc-of-queer-progress (what Sharon Cowan refers to as the "coherent 'progress' narrative" in this collection) - actually exposes the dangerous simplicity of many contemporary “LGBTIQ” narratives.

\footnotetext{
${ }^{65}$ Government Equalities Office, "Variations in Sex Characteristics Call For Evidence" Government Equalities Office website, January 17, 2019, accessed March 29, 2020, https://www.gov.uk/government/consultations/variations-in-sex-characteristics-call-for-evidence. 66 Ibid.

${ }^{67}$ Fae Garland and Mitchell Travis, "Legislating Intersex Equality: Building the Resilience of Intersex People through Law" Legal Studies, 38(4) (2018): 587 - 606, 598-599.

${ }^{68}$ See e.g. the high-profile report of the UN High Commissioner for Human Rights on "Discrimination and violence against individuals based on their sexual orientation and gender identity" which consistently refers to "intersex" throughout even though nominally relating to only to sexual orientation and gender identity concerns, United Nations High Commissioner for Human Rights (UNHCHR), 'Discrimination and violence against individuals based on their sexual orientation and gender identity' (4 May 2015) UN Doc No. A/HRC/29/23. ${ }^{69}$ See e.g. ILGA-Europe, "Intersex" ILGA Europe website, accessed March 29, 2020, https://www.ilgaeurope.org/what-we-do/our-advocacy-work/trans-and-intersex/intersex.
} 
First, and perhaps most obviously, if one accepts that experiences of intersex fall within the wider LGBTQ movement, they reveal a significant lacuna "inside" the UK's LGBT rights framework. At present, there are few, if any UK protections, which specifically address the unique position of intersex populations. ${ }^{70}$ This is true both in terms of guarantees against unwanted physical interventions (guarantees, which although imperfect, are secured for trans applicants through the GRA 2004) and accurate non-discrimination entitlements. It is not so much that intersex complicates the arc-of-queer-progress narrative. Rather, the striking invisibility of intersex perspectives in UK human rights, and the position of intersex populations as distant strangers to UK law, requires us to fundamentally rethink whether any broad statement about unidirectional queer progress can legitimately be made.

Second, intersex experiences also complicate what coming "inside" the law involves or, at least, they challenge us to reflect upon what meaningful inclusion requires for queer individuals. Is it possible that, as queers, we may find greater inclusion within the communitydevised structures that we playfully construct for ourselves outside the law than through the potentially rigid, imposed norms which are a pre-condition for obtaining insider status? In considering what it might mean to bring intersex lived experiences into UK law, there are a range of potential strategies.

Across Europe, a number of jurisdictions have sought to acknowledge intersex lives through expanding sex discrimination frameworks or by adopting alternative gender categories. ${ }^{71}$ These policies may be superficially welcome as a basic acknowledgment of

\footnotetext{
${ }^{70}$ Fae Garland and Mitchell Travis, "Legislating Intersex Equality: Building the Resilience of Intersex People through Law" Legal Studies, 38(4) (2018): 587 - 606. The UK approach is largely reflected of the legislative approach throughout Europe, see generally: Peter Dunne and Marjolein van den Brink, Trans and Intersex Equality Rights in Europe: A Comparative Analysis (Luxembourg: Publications Office of the European Union, 2018).

${ }^{71}$ See e.g. Germany and Austria.
} 
intersex experiences, and they may often conform with broader LGBTQ movement demands. Yet, such strategies are also potentially misrepresentative of, and may even supplant, actual intersex advocacy goals. In addition, they risk reproducing historic assumptions around intersex self-identification outside the binary. ${ }^{72}$

While, as Renz outlines, countries, such as Germany, are expanding gender options for intersex populations, many intersex persons actually do identify as male or female. ${ }^{73}$ The Declaration of the Third International Intersex Forum explicitly recommends "register[ing] intersex children as females or males" $" 74$ and many individuals find descriptions of intersex as outside the gender binary to be "othering" ${ }^{75}$ Indeed, within both UK and international intersex communities, there is considerable frustration that LGBTQ advocates (particularly within the sphere of gender recognition) frequently use intersex as a tool to challenge binary logics, without having to confront the shame, invisibility and physical violations, which often define intersex lived experiences. ${ }^{76}$ This frustration may, in some instances, run deeper, with Garland and Travis noting scepticism that mainstream LGBTQ activism has only brought intersex inside wider policy agendas in order to access additional funding sources. Whatever the truth in that regard, it is clear that, to the extent one considers non-discrimination and non-binary legislative responses as constitutive of greater legal inclusion, that approach is unlikely to satisfy the needs of intersex populations. In the UK, this may result in intersex communities

\footnotetext{
72 Lena Holzer, "Sexually Dimorphic Bodies: A Production of Birth Certificates" Australian Feminist Law Journal 45(1) (2019): 91-110, 100, who writes that "the majority of intersex persons identify with a binary gender/sex, mostly with the one assigned at birth, and only a minority identifies with a category other than female or male."

${ }^{73}$ Fae Garland and Mitchell Travis, "Legislating Intersex Equality: Building the Resilience of Intersex People through Law" Legal Studies, 38(4) (2018): 587 - 606, 598.

74 "Public Statement by the Third International Intersex Forum" ILGA-Europe, accessed March 29, 2020, https://www.ilga-europe.org/what-we-do/our-advocacy-work/trans-and-intersex/intersex/events/3rdinternational-intersex-forum.

${ }^{75}$ Lena Holzer, "Sexually Dimorphic Bodies: A Production of Birth Certificates" Australian Feminist Law Journal 45(1) (2019): 91-110, 100.

${ }^{76}$ In the Australian context, see: Morgan Carpenter, "The Normalization^ of Intersex Bodies and Othering of Intersex Identities in Australia” Bioethical Inquiry (2018) 15: 487-495, 492.
} 
voluntarily remaining as strangers to the law - preferring instead (as Garland and Travis suggest) to stay outside until they can control how the games of inclusion are played.

For many intersex individuals, coming "inside" the law requires institutional respect for bodily integrity and an end to unnecessary surgical interventions upon intersex youth. ${ }^{77}$ Such procedures, which became increasingly common in the latter half of the twentieth century, but which are now subject to considerable critique, compromise the physical autonomy of intersex populations. ${ }^{78}$ They are performed in circumstances where intersex infants - the individuals who will live with the consequences of surgery - have no opportunity to provide informed consent, ${ }^{79}$ where their parents may feel compelled by problematic societal norms ${ }^{80}$ and where too little weight is placed upon the absence of medical necessity. These are interventions, which, at least historically, have been motivated by questionable understandings of body and a belief that the sufficiency of one's sex characteristics defines gender status. ${ }^{81}$ To the extent that the supposed adequacy of an infant's penis may determine what legal gender is assigned (or what surgical procedures are performed), there is legitimate doubt as to whether

\footnotetext{
${ }^{77}$ Intersex NGO Coalition UK, NGO Report (for PSWG) to the 8th Report of the United Kingdom on the Convention on the Elimination of All Forms of Discrimination against Women (CEDAW), accessed March 29 , 2020 , https://tbinternet.ohchr.org/Treaties/CEDAW/Shared\%20Documents/GBR/INT_CEDAW_ICO_GBR_31475_E .pdf. The Coalition writes, at p. 4, that "[t] $\mathrm{the}$ United Kingdom is in breach of its obligations under the Convention on the Elimination of All Forms of Discrimination against Women to (a) take effective legislative, administrative, judicial or other measures to prevent involuntary, non-urgent surgery and other medical treatment and harmful practices of intersex persons based on prejudice, and (b) to ensure access to redress, and the right to fair and adequate compensation and rehabilitation for victims (CEDAW Arts. 1 and 5(a), General Recommendations No. 19 and 31)."

78 Jameson Garland and Santa Slokenberga, "Protecting the rights of children with intersex conditions from non-consensual gender-conforming medical interventions: the view from Europe" Medical Law Review 27(3) (2019): 482-508; Mary Newbould, "When Parents Choose Gender" Medical Law Rev 24 (2016): 474-496.

${ }^{79}$ Peter Dunne, “Towards Trans and Intersex Equality: Conflict or Complementarity?" in Jens Scherpe, Tobias Helms and Annatol Dutta, The Legal Status of Intersex Persons (Intersentia, 2018) 229.

${ }^{80}$ Jurg C. Streuli et al, "Shaping Parents: Impact of Contrasting Professional Counseling on Parents' Decision Making for Children with Disorders of Sex Development” Journal of Sexual Medical 10 (2013): 1953, 1958, Georgiann Davis and Erin L Murphy, "Intersex Bodies as States of Exception: An Empirical Explanation for Unnecessary Surgical Modification” Feminist Formations 25(2) (2013): 129-152, 144-145.

${ }^{81}$ Myra Hird, "Gender's Nature: Intersexuality, Transsexualism and the 'Sex"/“Gender' Binary" Feminist Theory 1(3) (2000): 347-344, 351.
} 
such reasoning benefits either the young person or society more generally. ${ }^{82}$ It is also uncertain whether the supposed social emergency occasioned by intersex justifies interventions which may rob individuals of their fertility or the capacity for future sexual sensation. ${ }^{83}$ For many advocates, it to those questions, which, irrespective of broader LGBTQ agendas, an intersexinclusive UK legal system must turn. And, indeed, if a queer reform movement really does seek to prioritise personal voice and experience, it is only by addressing concerns relating to bodily integrity that a queer framework, which is inclusive of intersex lives, can be achieved.

There are, however, valid questions as to how prominent a role law can (and should) play in the sphere of intersex, and how a queer response to the medicalisation of intersex youth might employ alternative, extra-legal strategies. By playing outside, can intersex individuals achieve solutions, which the limited scope and vision of law could never accommodate?

Beyond (the perhaps overstated) concerns that criminal prohibitions against surgical interventions on intersex bodies might deter other medically necessary treatments, there is the broader consideration of whether - if non-therapeutic procedures are motivated by binary social norms (what Fausto-Sterling famously termed the desire to "control those bodies that are so unruly as to blur the borders"84) - any remediating policy, which fails to challenge societal attitudes towards bodily diversity, might have only surface impact in terms of changing key stakeholder (e.g. doctors, parents, policy makers) approaches to intersex. This is not to suggest that law reform is irrelevant. There are coherent reasons why intersex advocates favour legal safeguards against unnecessary medical procedures. Indeed, as Garland and Travis

\footnotetext{
82 Julie Greenberg, "Defining Male and Female: Intersexuality and the Collision between Law and Biology" Arizona Law Review 41(2) (1999): 265-328, 271.

${ }^{83}$ Council of Europe Commissioner for Human Rights, Human Rights and Intersex (Council of Europe, 2015), p. 33.

${ }^{84}$ Anne Fausto-Sterling, Sexing the Body (Basic Books, 2008) 8.
} 
observe in this collection, Malta's Gender Identity, Gender Expression and Sex Characteristics

Act 2015 serves as an example of how statutory intervention can positively advance intersex autonomy - directly interrogating the social factors which drive so-called "normalizing" surgeries. ${ }^{85}$

Yet, a playfully, queer perspective on law must not only seek to change the applicable rules; it must engage with those social and cultural factors which initially encourage problematic practices. To the extent that ignorance or prejudice over intersex variance motivates continued medicalised responses to physical diversity, these phenomena require a broader consciousness-raising exercise. It is interesting that, in its landmark Concluding Observations to Germany in 2011, the United Nations Committee Against Torture (UN CAT) not only recommended "legal provisions in order to provide redress to the victims" of intersex surgeries administered without effective consent. ${ }^{86}$ The Committee also explicitly called upon the German authorities to "[e]ducate and train medical and psychological professionals on the range of sexual, and related biological and physical, diversity." ${ }^{87}$ In 2016 , the United Nations Committee on the Rights of the Child (UNCRC) made similar comments to the UK, calling upon this jurisdiction to "[e]ducate medical and psychological professionals on the range of sexual, and related biological and physical, diversity and on the consequences of unnecessary interventions for intersex children." 88 The UNCAT and CRC observations are not a repudiation of law, nor do they suggest that the vindication of key human rights can be achieved through

\footnotetext{
${ }^{85}$ Gender Identity, Gender Expression and Sex Characteristics Act 2015. Article 15(1) of the 2015 Act provides that "[i]t shall be not be lawful for medical practitioners or other professionals to conduct any sex assignment treatment and, or surgical intervention on the sex characteristics of a minor which treatment and, or intervention can be deferred until the person to be treated can provide informed consent." Article 15(2) goes on to clarify that "[i]n exceptional circumstances treatment may be effected once there is an agreement between the Interdisciplinary Team and the persons exercising parental authority or tutor of the minor who is still unable to provide consent: [p]rovided that medical intervention which is driven by social factors without the consent of the individual concerned will be in violation of this Act" (emphasis added).

${ }^{86}$ Committee against Torture, "Concluding observations of the Committee against Torture" (December 12, 2011) UN Doc No. CAT/C/DEU/CO/5, [20].

87 Ibid.

${ }^{88}$ Committee on the Rights of the Child, "Concluding observations on the fifth periodic report of the United Kingdom of Great Britain and Northern Ireland" (July 12, 2016) UN Doc No. CRC/C/GBR/CO/5, [47].
} 
solely extra-legal means. Rather, they are an honest assessment that, if state authorities (including officials in the UK) are going to bring intersex populations within the realm of required legal protection, this may necessitate interrogating what key actors understand that protection to mean for intersex individuals. A queer reform movement should embrace this opportunity for structural change, ensuring that, when intersex lives are brought inside UK law, this is a process which accurately reflects and foregrounds the lived experiences of those who are affected.

\section{Case Study III. Que(e)rying the Hostile Environment of Asylum}

"So nothing happened in your life which made you feel like you prefer men to girls?" 89

The importance of foregrounding the lived experiences of those cast as queer outsiders to law also resonates with discussions around how to make it easier for LGBT people to claim asylum in the UK. Laws criminalising homosexuality exist in at least 68 countries while laws limiting family recognition, restricting LGBT associations, and denying people the ability to legally change gender persist in many others. ${ }^{90}$ Over the past two decades, the UK has made space in law for the recognition and protection of some LGBT people, who flee such state-sanctioned homo/transphobic discrimination to seek asylum. In 1999, the UK recognised the possibility of sexual and gender minorities constituting a "particular social group" (a category protected by the UN Refugees Convention 1951) for the purposes of protection. ${ }^{91}$ In 2010 , the UK

\footnotetext{
${ }^{89}$ UKLGIG, Still Falling Short: The Standard of Home Office Decision-Making in Asylum Claims Based on Sexual Orientation and Gender Identity (UKLGIG, July 2018), p.19, accessed March 28, 2020, https://uklgig.org.uk/wp-content/uploads/2018/07/Still-Falling-Short.pdf.

90 See ILGA, "State Sponsored Homophobia: Global Legislation Overview Update” (December 2019) pp. 9-28, accessed March 28, 2020,

https://ilga.org/downloads/ILGA_World_State_Sponsored_Homophobia_report_global_legislation_overview_u pdate_December_2019.pdf.

${ }_{91}$ Islam (A.P) v Secretary of State for the Home Department of Regina v Immigration Appeal Tribunal and Another Ex Parte Shah (1999) 2 All ER 545 at 452 (Steyn LJ).
} 
Supreme Court expanded the reach of this protection by ruling that administrative expectations that gay and lesbian people could be "discreet" about their sexuality to avoid persecution were unlawful. ${ }^{92}$ More recently, jurisprudence from the Court of Justice of the European Union has affirmed the UK Supreme Court's rejection of discretion as a requirement and limited the use of stereotypes in decision-making (including the prohibition on the use of sexually explicit material as evidence). ${ }^{93}$

These progressive moves in the UK to bring LGBT people within refugee law, however, have emerged alongside new modes of state surveillance and scrutiny. The legal landscape facing LGBT(IQ) people who seek asylum in the UK is structured by competing vulnerabilities that inhibit the accommodation of queer sexualities and gender identities that cannot be indexed against stereotypes of what it means to be gay or trans. LGBT people who seek asylum typically demonstrate their vulnerability to human rights abuses by showing a "well-founded fear of persecution" as part of a "particular social group."94 Status determination processes make LGBT refugees vulnerable to removal if they cannot account for their experiences through rigid categories. Bureaucratic scrutiny of LGBT asylum claims also points to the vulnerabilities of an adjudication system plagued with anxieties about "bogus" claims that threaten the integrity of the state.${ }^{95}$ Political vulnerabilities shape the legal architecture that governs adjudication of such claims. Screening interviews, strict statutory or jurisprudential criteria on persecution, detention practices, and limited judicial review expose underlying state fears that "opening the floodgates" will compromise the integrity of the refugee system.

\footnotetext{
${ }^{92} H J$ (Iran) and HT (Cameroon) v Secretary of State for the Home Department (2010) UKSC 31.

93 Joined Cases C-199/12 to C-201/12 X (C-199/12), Y (C-200/12), Z (C-201/12) v Minister voor Immigratie en Asiel [2013] ECR I and Joined Cases C-148/13 to C-150/13 A (C-148/13), B (C-149/13), C (C-150/13) v Staatssecretaris van Veiligheid en Justitie [2014] ECR I.

${ }^{94}$ Sharalyn Jordan, "Un/Convention(al) Refugees: Contextualizing the Accounts of Refugees Facing Homophobia or Transphobic Persecution" Refuge 26 (2011): 165-182.

${ }^{95}$ Didier Fassin, “The Precarious Truth of Asylum" Public Culture 25(1) (2013): 39-63.
} 
Political vulnerabilities, expressed as fears or anxieties for protecting the integrity of state borders and legal process, materialise as a product of state immigration policy. In 2012, the UK government embarked on a process of creating a "hostile environment" for people who remained in the country without a regularised migration status. This was made possible through a series of policy, legislative, and regulatory measures that "showed contempt" towards migrants. ${ }^{96}$ As S Chelvan details in Chapter 4, for individuals like Aderonke Apata, a hostile immigration bureaucracy - one that defaults to suspicion, disbelief, and scrutiny when faced by people who make asylum claims - creates hurdles for queer outsiders to overcome in order to gain asylum. The Home Office's statistics on sexual orientation claims reveal the scale of how many people fail to overcome such hurdles: only about $30 \%$ of asylum applications on the basis of sexual orientation were accepted at first instance. ${ }^{97}$

In the UK, the progressive willingness to consider LGBT asylum claims "inside the law" has also led to the reproduction of sexual and gender stereotypes. While the scale of rejected LGB asylum claims is largely consistent with non-sexuality-based asylum claims, queer people seeking asylum in the UK are faced with a pernicious "culture of disbelief" when it comes to demonstrating the veracity of their sexuality and the depth of the harm that they face if returned. ${ }^{98}$ The UK Lesbian and Gay Immigration Group has documented how this functions in practice. In one case, a gay man who described how his "schoolboy friendship"

\footnotetext{
${ }^{96}$ Frances Weber, "On the creation of the UK's 'hostile environment"” Race \& Class 60(4) (2019): 76-87, 77.

${ }^{97}$ UK Home Office, "Experimental Statistics: Asylum Claims on the basis of sexual orientation" (August 2019), accessed March 28, 2020, https://www.gov.uk/government/publications/immigration-statistics-year-endingjune-2019/experimental-statistics-asylum-claims-on-the-basis-of-sexual-orientation. The Home Office also notes that $38 \%$ of asylum appeals in relation to a negative decision are allowed.

${ }^{98}$ UKLGIG, "Missing the Mark: Decision Making on Lesbian, Gay, Bisexual, Trans, and Intersex Asylum Claims (September 2013), accessed March 28, 2020, https://uklgig.org.uk/wpcontent/uploads/2014/02/Missing-the-Mark.pdf; Moira Dustin, "Many Rivers to Cross: The Recognition of LGBTQI Asylum in the UK" International Journal of Refugee Law 30(1) (2018): 104-127; Jenni Millbank, "From Discretion to Disbelief: Recent Trends in Refugee Determinations on the Basis of Sexual Orientation in Australia and the United Kingdom" The International Journal of Human Rights 13(2-3) (2009): 391-414; Senthorun Raj, "A/Effective Adjudications: Queer Refugees and the Law” Journal of Intercultural Studies 3(4) (2017): 453-468.
} 
developed into a romantic relationship was dismissed because he failed to remember the exact dates of its beginning and anniversaries (this relationship happened 20 years earlier). ${ }^{99}$ In another case from August 2016, a bisexual man disclosed that he wished to remain in the UK and marry his male partner despite his family wishing for him to return and marry a woman. Rather than recognise the unique situation faced by bisexuals, the Home Office interviewer queried the "issue" of persecution (presumably assuming that a bisexual man could be "safe" if they married someone of the opposite sex). ${ }^{100}$ In February 2017, a lesbian woman had her claim refused because she could not provide corroborating evidence of her relationship with a woman (such as evidence that they had lived together) because it was secret. ${ }^{101} \mathrm{~A}$ trans woman was questioned about whether she had surgery (which assumes surgical intervention is what it means to be trans - a concept which UK law had already abandoned as part of the GRA 2004). ${ }^{102}$

The above encounters with immigration officers in the UK evince how the uses of sexual and gender stereotypes in asylum law in the UK police the boundaries of what counts as "authentic" homosexuality, bisexuality, and being trans. This administrative policing situates "inauthentic" queers with contested or complicated accounts of their sexuality or gender identity outside the zone of protection. As Jenni Millbank documents in her work, LGBT people's experiences of lodging an asylum claim expose their unique vulnerabilities to degrading processes that both define and confine their sexualities and gender identities according to scripts of genital activity, public visibility, pop culture, and medical transitions

\footnotetext{
${ }^{99}$ UKLGIG, "Still Falling Short: The Standard of Home Office Decision-Making in Asylum Claims Based on Sexual Orientation and Gender Identity" (July 2018), p. 18, accessed March 28, 2020, https://uklgig.org.uk/wpcontent/uploads/2018/07/Still-Falling-Short.pdf, p 18.

${ }^{100}$ Ibid, p. 19.

${ }^{101}$ Ibid, p. 30.

${ }^{102}$ Ibid, p. 31.
} 
while dismissing as "self-serving" those who hew too closely to those stereotypes. ${ }^{103}$ One individual who, in May 2016, was told that he did not need to be in a relationship or belong to an LGBT social group to prove the veracity of his sexuality, was subsequently asked whether he had done anything to "enhance" his claim. ${ }^{104}$ It is a Catch-22. State bureaucrats demand that a person produce evidence of their claim for the purpose of inclusion while also excluding (as incredible) evidence that seems too neat or scripted. LGBT people are coerced to subscribe to harmful evidentiary practices (performing "gayness").

It is understandable, then, that advocates (like UKLGIG) and scholars (like Chelvan) have offered some prescriptive suggestions as a way of creating a more "open and reassuring environment" for LGBT people to tell their stories of displacement. ${ }^{105}$ UKLGIG's recent submission to the review of this process suggests that improved policy is insufficient and that decision-makers require ongoing training on these issues to improve the practice of adjudicating LGBT asylum claims. ${ }^{106}$ Chelvan suggests that improving practice requires an institutional shift in approach: moving away from identity-based narratives to make room to accommodate accounts of “difference". In Apata's case, her claim for asylum - and recognition

\footnotetext{
${ }^{103}$ See generally Jenni Millbank, "Fear of Persecution or a Just a Queer Feeling?: Refugee Status and Sexual Orientation in Australia" Alternative Law Journal 20(6) (1995): 261-265; Jenni Millbank, "Imagining Otherness: Refugee Claims On The Basis Of Sexuality In Canada and Australia" Melbourne University Law Review 26(7) (2002): 144-177; Jenni Millbank, "Gender, Sex and Visibility in Refugee Claims on the Basis of Sexual Orientation" Georgetown Immigration Law Journal 18 (2003): 71-110; Jenni Millbank, “A Preoccupation with Perversion: The British Response to Sexual Orientation Refugee Claims, 1989-2003" Social \& Legal Studies 14(1) (2005): 115-138; Jenni Millbank, "The Ring of Truth: A Case Study of Credibility Assessment in Particular Social Group Refugee Determinations" International Journal of Refugee Law 21(1): (2009). 1-33; Jenni Millbank, "From Discretion to Disbelief: Recent Trends in Refugee Determinations on the Basis of Sexual Orientation in Australia and the United Kingdom" The International Journal of Human Rights 13(2-3) (2009): 391-414; See Laurie Berg and Jenni Millbank, "Developing a Jurisprudence of Transgender Particular Social Group" in Thomas Spijkerboer (ed) Fleeing Homophobia: Sexual Orientation, Gender Identity and Asylum (2013), 121-153.

${ }^{104}$ UKLGIG, "Still Falling Short: The Standard of Home Office Decision-Making in Asylum Claims Based on Sexual Orientation and Gender Identity" (July 2018), p.18, accessed March 28, 2020, https://uklgig.org.uk/wpcontent/uploads/2018/07/Still-Falling-Short.pdf.

${ }^{105}$ Ibid, pp. 18-10. See also S. Chelvan's contribution in Chapter 4 of this edited collection.

${ }^{106}$ UKLGIG, "Submission to the Independent Chief Inspector of Borders and Immigration inspection of the Home Office's Presenting Officers' function" (January 2020), p. 2, accessed March 20, 2020, https://uklgig.org.uk/wp-content/uploads/2020/02/UKLGIG-submission-to-ICIBI-inspection-of-presentingofficers-Jan-2020-FINAL.pdf.
} 
as a lesbian - was ultimately successful when she could articulate her desires, discuss her previous marriage to a man, and explain her delayed disclosure about her sexuality. Creating a welcome, rather than hostile, environment for people to come into is essential for queer claims that do not fit linear and stereotypical accounts of sexuality or gender. Making space for queers seeking asylum to come inside both the country and its legal system - to tell their stories enables greater recognition of protection claims. The process of making space is not simply about securing administrative convenience or improving legal integrity. These legal interventions are important as the material consequences of rejecting an asylum claim (and forced removal) are dire for those who face persecution on return to their country of origin.

However, displacing the anxiety-laden legal architecture that scaffolds the UK's asylum adjudication space with the "welcoming of differences" risks limiting queer disruptions to the integrity of the space itself. Eddie Bruce-Jones' account of "death zones" and "comfort zones" in Chapter 3 aptly articulates how coming inside the ambit of legal (refugee) protection individualises what is a structural, cross-border problem of homophobia and transphobia. This is not to say that individual litigation and casework should be rejected but Bruce-Jones suggests that we need to rethink the political consequences of the "progressive" legal claims we make for inclusion. This means moving away from the "comfort" provided by human (refugee) rights discourse that situates some states as "better" than others and confronting how violence materialises for displaced people on the peripheries of a racist, xenophobic state that purports to care for them. This violence is acutely apparent in the ways in which LGBT people who seek asylum have sexual and gender categories imposed on their stories and are made to conform to them. This is also evident in British political rhetoric that casts migrants as 
intolerant and a source of homo/transphobia while state institutions (such as the Home Office) dismiss the veracity of LGBT people who flee such "homo/transphobic migrants."107

Queer outsiders to refugee law require us (as scholars and advocates) to play with legal categories that force people to subscribe to static, essentialist, and transhistorical ideas of sexuality and gender. For Moira Dustin and Nina Held, a bureaucratic insistence on establishing clear accounts of persecution and linear narratives about sexuality is incongruous with individual experiences which are largely fluid and contested. ${ }^{108}$ To address this tension and foreground fluidity - means advocates, lawyers, and decision-makers need to consider playing around with individualised assessments of gender and sexuality and to engage with queer (refugee) outsiders in less harmful ways. This process of playing with law could allow for self-determination of sexuality/gender but require scrutiny over the scope of the protection/persecution claim or it could result in undoing the process of verification altogether and allow people to self-determine both their sexuality/gender and need for protection. But, as Bruce-Jones makes clear in his chapter, we also need to look outside law and beyond borders to a world where formal citizenship is not the key to safety or visibility. Those queers who literally remain "outside" the ambit of state refugee law (such as people who are internally displaced) require forms of engagement that are political, social, and economic rather than legal

\footnotetext{
107 Theresa May, while acknowledging the colonial legacy of anti-gay laws, moralised about the importance of protecting LGBT people who seek asylum from the "terrible suffering" they face elsewhere and how the UK stands as a beacon for the protection of LGBT rights. These claims were made while the Home Office continued to remove a number of LGBT people who had sought asylum. See Nick Duffy, "Prime Minister Theresa May challenged over deportation of LGBT asylum seekers", PinkNews, October 25, 2017, accessed March 28, 2020, https://www.pinknews.co.uk/2017/10/25/prime-minister-theresa-may-challenged-over-deportation-of-lgbtasylum-seekers/. Jasbir Puar describes this political use of LGBT inclusion as a barometer of state progress as "homonationalism", see Jasbir Puar, "Homonationalism as Assemblage: Viral Travels, Affective Sexualities" Jindal Global Law Review 4(2) (2013): 23-43, 24. Kay Lalor elaborates in Chapter 2 on how this rhetoric functions to promote the political "progressiveness" of the UK in relation to LGBT rights. This also relates to the way migrants are positioned in discussions about including LGBT content in sex and relationships education.

${ }^{108}$ Moira Dustin and Nina Held, "In or Out: A Queer Intersectional Approach To 'Particular Social Group' Membership and Credibility in SOGI Asylum Claims in Germany and the UK" Genius 2 (2018): 74-87, 1.
} 
to address their human rights violations. Queering international (refugee) law involves disrupting the existence of borders and recognising collective forms of (irregular) citizenship that do not conform to nationalistic notions of (homo)sexual and (trans)gendered belonging. ${ }^{109}$

\title{
Case Study IV. The Queer Politics of LGBT Education
}

\begin{abstract}
"It would have meant a great deal to me to have had LGBT issues as part of the curriculum when I was growing up. I went through a great deal of self-loathing then, and began to self-harm. Seeing people like me, who were queer and Muslim, would have been very empowering and made my life easier." 110
\end{abstract}

Que(e)rying the politics of belonging and protection in relation to people who seek asylum or seek legal gender recognition also connects to recent legislative attempts in the UK to protect the wellbeing of young LGBT people through a new national curriculum dealing with sex and relationships. In 2019, the Westminster Parliament voted to adopt a new LGBT-inclusive Relationships and Sex Education (RSE) curriculum that would make LGBT content compulsory in secondary schools and voluntary in primary schools. ${ }^{111}$ The adoption of these regulatory measures generally, and the proposed implementation of LGBT content specifically, generated heated public debates. ${ }^{112}$ These debates were largely caricatured by media outlets and protestors as a conflict between state mandated inclusion of LGBT content, on one hand, and the undermining of parental authority, particularly of religious and ethnic minorities, on

\footnotetext{
${ }^{109}$ Bina Fernandez, "Queer Border Crossers: Pragmatic Complicities, Indiscretions and Subversions" in Dianne Otto (ed) Queering International Law: Possibilities, Alliances, Complicities, Risks (Routledge, 2017): 193-211, 211.

${ }^{110}$ Saima Mir, "'I feel caught in the middle': queer Muslims on the LGBTQ lessons row", The Guardian, March 27, 2019, accessed March 28, 2020, https://www.theguardian.com/education/2019/mar/27/caught-in-middlequeer-muslims-lgbtq-lessons-schools-protests.

${ }^{111}$ Relationships Education, Relationships and Sex Education and Health Education (England) Regulations 2019.

${ }^{112}$ Benjamin Butterworth, "MPs for LGBT inclusive sex and relationship education from primary school", iNews, March 28, 2019, accessed March 28, 2020, https://inews.co.uk/news/education/lgbt-sex-relationshipeducation-mps-support-504670.
} 
the other. ${ }^{113}$ Most sensationally, the protests against similar content at a primary school in Birmingham generated a legal conflict about the extent to which the inclusion of LGBT experiences in school curriculums could be objected to, and what (if any) legal sanctions could be used by the state to block such objections. ${ }^{114}$

Before unpacking these debates, it is necessary to contextualise how policy and legal responses in the UK to matters of LGBT wellbeing in schools capture the movement of queer children as outsiders (ignored and feared in law) to insiders (protected and supported in law). In 1988, the British government legislated to prevent local authorities from funding school content that "promoted" homosexuality as a "pretended family relationship" (commonly referred to as Section 28). ${ }^{115}$ LGBT content, specifically homosexuality, was positioned as outside the zone of both legal relationship validity and social acceptability. Queer children were rendered absent through this law.

In the last two decades, successive UK governments have remedied this absence and expressed greater interest in, and willingness to include, discussions of homosexual and trans identities in the classroom. The UK government's sex and relationship guidance just prior to Section 28's repeal (published in 2000) suggested that teachers should deal "honestly" and "sensitively" with questions about sexuality. ${ }^{116}$ The newly revised sex and relationship guidance (published in 2019) goes much further and recognises the importance of progressing discussions of LGBT intimacies and identities (at staged levels of complexity and depth) across

\footnotetext{
113 Nazia Parveen, "Parents complain to Manchester schools about LGBT lessons", The Guardian, March 19, 2019, accessed March 28, 2020, https://www.theguardian.com/education/2019/mar/19/fresh-complaints-aboutlgbt-lessons-at-greater-manchester-primary-schools.

114 "Parkfield Community School: Ofsted says LGBT lessons are 'appropriate'”, BBC News, March 2, 2019, accessed March 28, 2020, https://www.bbc.co.uk/news/uk-england-birmingham-47536752.

${ }^{115}$ Local Government Act 1988 (UK), s. 28.

${ }^{116}$ UK Department for Education, "Sex and Relationship Education Guidance", UK Government website, July 2000, accessed March 28, 2020, https:/www.gov.uk/government/publications/sex-and-relationship-education.
} 
all school years. ${ }^{117}$ Stonewall's advocacy and research on this topic has been of particular importance in achieving law reform. As its recent report on the nature of bullying in schools points out, inclusion matters because it provides young LGBT people with affirmation of their desires and interests, visibility to counter their erasure and isolation, access to information to improve their sexual health, and awareness of diversity to counter the hate, stigma, and discrimination they face. ${ }^{118}$ When approached in light of equality law in England, these LGBTinclusive measures in schools aim to increase understanding of the intersection between law and people's lives, particularly in relation to public sector obligations to "foster good relations" and "eliminate discrimination". ${ }^{119}$ Despite these statutory changes, the expansion of religious schools and parental objections to sex education, coupled with political anxieties over "cultural sensitivity", have exposed the limits of existing legal measures of inclusion: some (religious) schools can be dismissive, and parents can withdraw their children (under the age of 15) from the discussion of LGBT lives, even though schools must include some discussion of them. ${ }^{120}$

This confusing form of inclusion - naming LGBT people as a group to proactively include in classroom discussions and then rendering that inclusion conditional (on religious sensitivities) - resonates with what Kay Lalor refers to in Chapter 2 as an impasse or paradox. In her contribution, Lalor traces how recent legislative recognition of Britain's responsibility

\footnotetext{
${ }^{117}$ UK Department for Education, "Relationships Education, Relationships and Sex Education (RSE) and Health Education Statutory Guidance" Department of Education website, June 2019, accessed March 28, 2020, https://assets.publishing.service.gov.uk/government/uploads/system/uploads/attachment_data/file/805781/Relati onships_Education_Relationships_and_Sex_Education_RSE_and_Health_Education.pdf.

${ }^{118}$ See: Stonewall UK, "School Report: The Experiences of Lesbian, Gay, Bi and Trans Pupils in Britain's Schools", Stonewall website, November 2017, accessed March 28, 2020, https://www.stonewall.org.uk/system/files/the_school_report_2017.pdf. Stonewall was founded by activists campaigning against Section 28.

${ }^{119}$ Equality Act 2010 (UK), s. 149.

${ }^{120}$ Paul Johnson and Robert Vanderbeck, Law, Religion and Homosexuality (Routledge, 2014), pp. 190-197; UK Department for Education, "Relationships Education, Relationships and Sex Education (RSE) and Health Education Statutory Guidance" Department of Education website, June 2019, March 28, 2020, https://assets.publishing.service.gov.uk/government/uploads/system/uploads/attachment_data/file/805781/Relati onships_Education_Relationships_and_Sex_Education_RSE_and_Health_Education.pdf, pp. 15, 17-18.
} 
to promote LGBT rights, including acknowledgment of how Britain is implicated in existing laws criminalising homosexuality, creates hierarchies of inclusion/exclusion and home/elsewhere. Lalor discusses how a "Global LGBT Rights Debate" in Westminster rendered the "outside" (of the UK) as a space of continuing violence against LGBT people while implicitly claiming the "inside" (of the UK) as a space of relative safety and comfort. The inside/outside emerged as co-constituting positions in an elastic temporal and spatial relationship. In other words, the British Empire's seemingly former history as a homophobic regime that exported its homophobia outside its (even at the time contested) borders was redressed through a contemporary obligation for the British government/parliament to use the resources inside its jurisdiction (such as a parliamentary debate) to challenge homo/transphobic outsiders (such as postcolonial governments) in other countries. Yet, as Lalor maintains, a colonial register structures the ways in which MPs use diplomatic engagement to assume a kinship with other LGBT people while distancing their experiences of structural violence from those who they claim are "more seriously" oppressed. This coloniality re-emerges in the current debates about including LGBT content in schools. Here, the British government recognises its historical ignorance or marginalisation of LGBT people and then positions itself as a contemporary bearer of pro-LGBT inclusion values. These inclusion values are realised by a mandated cultivation in the curriculum, even if state values position Muslims or minority ethnic communities as (homo/transphobic) outsiders.

The limits of inclusion are a productive space to think about what is gained from legally mandating LGBT inclusive-curriculums and how exemptions or withdrawals from these programmes prompt alternative interventions by activists, particularly those from minority ethnic and religious backgrounds. This is exemplified in the High Court's recent decision to bar certain anti-LGBT protestors from a school in Birmingham. In Birmingham City Councilv 
Afsar (2019), the High Court had to consider whether to uphold an injunction against parents/guardians who had engaged in relentless protests just outside the school gates about the inclusion of LGBT content at Anderton Park Infant and Junior School. It is important to note that the protests that gave rise to this litigation do not deal with the new RSE curriculum (due to be implemented in September 2020) but rather were concerned with school measures (such as books with LGBT content in the library) aimed at promoting the inclusion of LGBT people. These measures, erroneously linked to a related programme called "No Outsiders", became the subject of intense animosity among a select group of parents and local community members who felt the school was engaging in "LGBT sexual education."121

The case raises a number of procedural and technical issues, which we do not address here. What is particularly useful for us to draw out in this jurisprudence is the way in which space functions both literally and metaphorically in the argument between parties to determine the extent to which the law accommodates pro-LGBT content and parental rights to protest that content. In their submissions, the defendants essentially argued that "the teaching of LGBT issues" unlawfully discriminated against British Pakistani Muslim children (and their parents) to the extent that they could not preserve their cultural values that are "centred on heterosexual relationships in marriage." 122 For them, the school's inclusion of LGBT content alienated some children and parents - made them outsiders to the school (as many were literally protesting outside the school gates). To the school, these outsiders (many of whom were not connected to the school) became an enduring "nuisance". ${ }^{123}$ Their abusive conduct had detrimental impacts

\footnotetext{
${ }^{121}$ Birmingham City Council v Afsar (No 3) [2019] EWHC 3217 (QB), [3]. "No Outsiders" was a programme that was taught at another school in Birmingham, where primary school pupils were taught about equalities, rights, and differences. The programme was discontinued at the school following the withdrawal of Muslim students from the school. See Nazia Parveen, "Birmingham school stops LGBT lessons after parents protest", The Guardian, March 4, 2019, accessed March 28, 2020, https://www.theguardian.com/education/2019/mar/04/birmingham-school-stops-lgbt-lessons-after-parentprotests.

${ }_{122}$ Birmingham City Council v Afsar (No 3) [2019] EWHC 3217 (QB), [37] (Warby J).

${ }^{123} \mathrm{Ibid},[40]$ (Warby J).
} 
on the wellbeing of staff and the noise generated by the protests inhibited teaching at the school. ${ }^{124}$ In issuing a permanent injunction against some of the protestors, the Court literally demarcated the boundaries that they could occupy. The individuals concerned were still allowed to protest but they were pushed outside the gates onto a nearby park and blocked from using a megaphone to amplify their messages. ${ }^{125}$

As this case makes apparent, inclusion was a polarising flashpoint for two marginalised communities in the UK (LGBT people and Muslims). Legal address (via judicial review) presented this polarisation as a conflict of rights: religious expression and cultural identity placed in opposition to LGBT rights and lives. Judicial review is invoked to mediate between protestors' demands that the school withdraw LGBT content (such as books), along with their threats to withdraw children from the school if this is not done, and the school's (legally mandated) interest in promoting equality. But here, an injunction to permanently exclude is impossible. On one hand, some parties are required to be inside the school when it comes to their children. On another hand, parties with children at the school are not able to block parts of the curriculum that deal with LGBT people. As Cooper notes, these "conflicts over withdrawal" involve generative contact between various parties (the school, the council, protestors, parents, LGBT people/activists) and stitch them together both inside (the school) and outside (the protest). ${ }^{126}$

Some LGBTIQ Muslims note, however, that framing the protest as a conflict between religion and sexuality (where one must cede to the other) is unproductive because it erases their experiences of both. Ferhan Khan suggests that we "need to give queer Muslims a voice. Let

\footnotetext{
${ }^{124}$ Ibid, [90] - [95] (Warby J).

${ }^{125} \mathrm{Ibid},[120]$ (Warby J).

${ }^{126}$ Davina Cooper, Feeling Like a State: Desire, Denial, and the Recasting of Authority (Duke University Press, 2019), pp. 99-100.
} 
us go into the schools and talk to the children. Give us the brief, the resources and the platform - if you really care." 127 Khan's words speak to being queer on the outside of a debate that prioritises white LGBT voices and straight Muslim perspectives. Rather than subscribe to law's spatialising tendency to create an inside/outside or religion/sexuality binary in resolving complaints of discrimination - a tendency that is deeply racialised as Lalor and Bruce-Jones indicate - Khan's words gesture to why it is important to highlight what queer outsiders can offer. Specifically, the state giving resources to queer Muslims to come inside schools might provide a route to build solidarity between LGBT people and Muslims. New statutory guidance relating to RSE might be an avenue to enable this as it provides an infrastructure to both affirm LGBT young people and address intersecting experiences of bullying, harassment, and discrimination. Yet, legal regulation alone is insufficient to address or mediate between minoritarian differences that arise between and within communities (as the protests in Birmingham make clear). We need to think creatively from outside law about how we might resource cross-cultural dialogues outside the curriculum - outside mandated requirements using alternative educational platforms (such as social media) and occupying non-school spaces (such as places of worship or community halls).

Moreover, we might want to pause and consider how inclusion of LGBT content in the curriculum strengthens state institutionalisation of norms relating to "proper" or "good" sexuality, intimacy, and gender. Much like norms governing the adjudication of asylum claims that Chelvan and Bruce-Jones make clear, and the recognition of trans and non-binary identities as illustrated by Renz and Cowan, state governance of sexuality and gender risk reproducing racialised, ableist, and heteronormative ideas. As Felicity Adams and Fabienne Emmerich

\footnotetext{
${ }^{127}$ Saima Mir, "'I feel caught in the middle': queer Muslims on the LGBTQ lessons row", The Guardian, March 27, 2019, accessed March 28, 2020, https://www.theguardian.com/education/2019/mar/27/caught-in-middlequeer-muslims-lgbtq-lessons-schools-protests.
} 
argue in Chapter 5 about LGBTIQ incarceration, prisons exemplify the consequences of state control over the sex, gender, and sexuality of outsiders (prisoners) through the exclusion of trans people, isolation of vulnerable queers, and intense scrutiny of queer relationships. They discuss how recent prison policies, for example, insist that trans prisoners undergo a permanent gender transition and perform a binary gender identity to be institutionally accommodated. Further, they outline how caring and consensual (not always sexual) interactions between those in the prison estate threaten the "equilibrium" of prison by allegedly making other (heterosexual) prisoners feel hostile about their inability to engage in relationships. As Grietje Baars notes, heterosexual people also face the "distributive effects" of a state control of outsiders that render their (heterosexual) intimacies impossible. ${ }^{128}$

While the new RSE curriculum to be implemented in England accommodates a much broader range of sexual interactions and relationship statuses, the British government's "respect" for different kinds of intimacies and identities is circumscribed. The guidance reifies those relationships that are "committed" and "stable" while affirming why "marriage is an important choice." ${ }^{129}$ When it comes to sex, echoing prison policy, the guidance for secondary schools emphasises safeguarding and risk management by teaching pupils to manage the "harms" present in online spaces, understand legal penalties for the sharing of self-produced sexually explicit material, engage with criminal law relating to sexual assault, and grasp the consequences of sexually transmitted infections. ${ }^{130}$ Young people are encouraged on one hand to respect platonic and other relationships while encouraged to defer the sexual kind.

\footnotetext{
${ }^{128}$ Grietje Baars, “Queer Cases Unmake Gendered Law, Or, Fucking Law's Gendered Function” Australian Feminist Law Journal 45(1) (1019): 15-62, 47.

${ }^{129}$ UK Department for Education, "Relationships Education, Relationships and Sex Education (RSE) and Health Education Statutory Guidance", Department of Education website, June 2019, accessed March 28, 2020 , https://assets.publishing.service.gov.uk/government/uploads/system/uploads/attachment_data/file/805781/Relati onships_Education_Relationships_and_Sex_Education_RSE_and_Health_Education.pdf, p. 27. ${ }^{130}$ Ibid, pp. 28-29.
} 
These examples show us why remaining outside law is a productive way to challenge the state's policing functions in relation to transgressions of sexual and gendered morality. In both prisons and schools, even if to differing degrees, queer pleasures and relationship pluralities remain outside the scope of state inclusion. From this outside vantage point, we can take account of the relationship between regulation of RSE and other laws to recognise the divergences between state education that encourages relationship plurality (even if only to the extent of long-term committed relationships), and other laws that police or refuse relationship plurality. This is evident in how marriage (and to a lesser extent civil partnerships) are privileged (in law) at the expense of other meaningful caring, non-dyadic or non-sexual relationships. ${ }^{131}$ Law should make room for LGBTIQ people to pursue their intimacies from the outside, too.

\section{Confronting Queer Outside(r)s}

The case studies discussed above show how expanding the "inside" of law to reach new individuals, issues, and institutions can "colonise" the generative possibilities of the outside. Our critical engagements with the cases studies above show that queer outsiders coming in, seeking inclusion in legal spaces, have redefined the spatiality and operation of particular laws in divergent ways. The case studies we have discussed point to how state control over sexuality and gender (in legal gender recognition, intersex, asylum law, and education policy) make protection and affirmation conditional on the performance of authenticity - obliging queer

\footnotetext{
${ }^{131}$ For a discussion on same-sex relationship recognition and relationship diversity, see Alexander Maine, "The Hierarchy of Marriage and Civil Partnerships: Diversifying Relationship Recognition" in Frances Hamilton and Guido Noto La Diega (eds) Same-Sex Relationships, Law and Social Change (Routledge, 2020) 209.
} 
individuals to frame, shape and (even) contort their understandings of identity and body into rigid, inflexible norms of gender and sexuality.

The chapters in our collection point out that queer analysis can risk objectifying people and the materiality of their experiences by treating them as conceptual categories. Intersex rights and activism, as outlined in Garland and Travis" interviews, contest the queer "othering" of their bodies and identities in law. As Adams and Emmerich observe both in case law and existing policies, prisons are not romantic spaces of queer intimacy or sites for reform to improve upon. Chelvan and Bruce-Jones use immigration bureaucracy to show how people who seek asylum are, and should not be, made queer to legal mechanisms of protection. Renz details how the proliferation of gender categories may enable the "queering" of a binary as a conceptual matter, but it does not address the structural realities or embodied experiences of oppression that non-binary people face. In Cowan's discussions with trans people, equality cannot be dismissed as a concept in critique because it is a central material and embodied claim of optimism, particularly for trans people who seek social belonging and affirmation. Lalor captures how talking about (in abstract terms), rather than talking with, marginalised LGBTIQ people reproduces colonial hierarchies of insider/outsider, saviour/victim, and safety/oppression.

LGBTIQ reforms expose how legal systems can open up ways of imagining sex, gender, and sexuality theoretically or conceptually, while foreclosing them in practice. There is much to be gained by rendering the investment law has in certainty less secure (making space for fluidity, anxiety, and uncomfortability). For us, the queer analyses of legal interventions assembled in this collection are not about romanticising specific modes of analysis or using experiences of injustice to develop a theoretical agenda. Instead, each contributor engages with 
the material and normative consequences of staying inside and/or playing outside law. Taken together, they navigate how this involves withdrawal from particular sites of legal recognition and protection, while seeking inclusion in others. As Baars suggests, withdrawal of our lives from the inside of law - to engender a strike - is a way to contest the state institutionalisation of gender and sexuality. ${ }^{132}$ Cooper, in a different vein, observes that we can also think about the drama of withdrawal as a form of relation and refiguration: withdrawing involves contact between parties who withdraw (legal protection or social services) from others (LGBTIQ people) and this reshapes how these parties are governed by that withdrawal. ${ }^{133}$ Queers can come inside and play outside law, in different arenas and subdisciplines of law, at the same time.

Playing with queerness outside law - and withdrawing from specific legal interventions - is a way to pursue activism and solidarity (whether it involves global LGBTIQ rights, intersex autonomy, refugee protection, or dismantling prisons). Intersex remains outside both law and queer (activist) agendas - to refuse "disciplining" by legal, medical, and academic knowledges. Queer decolonial and migration activisms contest the punitive impacts of legal recognition or incorporation/inclusion that reify xenophobic state politics while demonising those who migrate from "elsewhere." Queer abolition speaks to the importance of legally withdrawing from carceral systems to avoid the premature death and systemic harms faced by racialised and poor populations. Alternatively, intersex and non-binary activisms point to the possibility of removing (legal) gender as a site of (legal) governance.

\footnotetext{
132 Grietje Baars, “Queer Cases Unmake Gendered Law, Or, Fucking Law’s Gendered Function” Australian Feminist Law Journal 45(1) (2019): 15-62, 21.

${ }^{133}$ Davina Cooper, Feeling Like a State: Desire, Denial, and the Recasting of Authority (Duke University Press, 2019), p. 31.
} 
The different forms of play imagined in this collection also carry productive risks. We urge scholars, activists, and advocates to pursue further questions in projects of LGBTIQ law reform and political activism. We think it is important for our legal futures to keep interrupting with critical questions. What would it mean to queer the legal insistence in some areas of defining sex/gender or relationships? What might be gained by refusing borders? What alternatives to recognition and punishment can we create for accountability? How might we come together, as disparate and intersecting demographics, to do this work? In responding to these sorts of questions, we are be better placed to support LGBTIQ people both inside and outside the law. 


\section{References}

Aikan, Jordan. "Promoting an Integrated Approach to Ensuring Access to Gender Incongruent Health Care" Berkeley Journal of Gender, Law and Justice 31(1) (2016): 1.

Baars, Grietje. “Queer Cases Unmake Gendered Law, Or, Fucking Law’s Gendered Function” Australian Feminist Law Journal 45(1) (1019): 15.

Barlow, Anne. "A new approach to transsexualism and a missed opportunity?" Child and Family Law Quarterly 13(2) (2001): 225-240.

Berg, Laurie Berg and Jenni Millbank, "Developing a Jurisprudence of Transgender Particular Social Group" in Thomas Spijkerboer (ed) Fleeing Homophobia: Sexual Orientation, Gender Identity and Asylum (2013), 121-153.

Bonifacio, Herbert J and Stephen M Rosenthal, "Gender Variance and Dysphoria in Children and Adolescents" Paediatric Clinics of North America 62(4) (2015): 100. 
Brunskell-Evans, Heather. “The Medico-Legal 'Making' of the Transgender Child” Medical Law Review 27(4) (2019): 640-657.

Butterworth, Benjamin. "MPs for LGBT inclusive sex and relationship education from primary school", iNews, March 28, 2019. Accessed March 28, 2020, https://inews.co.uk/news/education/lgbt-sex-relationship-education-mps-support-504670.

Canoot, Pieter. "The pathologisation of trans* persons in the ECtHR's case law on legal gender recognition” Netherlands Quarterly of Human Rights 37(1) (2019): 14-35.

Carpenter, Morgan. “The Normalization^ ${ }^{\wedge}$ of Intersex Bodies and Othering of Intersex Identities in Australia" Bioethical Inquiry (2018) 15:487-495.

Cooper, Davina. Feeling Like a State: Desire, Denial, and the Recasting of Authority (Duke University Press, 2019).

Council of Europe Commissioner for Human Rights, Human Rights and Intersex (Council of Europe, 2015).

Cowan, Sharon. "That Woman Is a Woman!" the Case of Bellinger v. Bellinger and the Mysterious (Dis) appearance of Sex: Bellinger v. Bellinger [2003] 2 All ER 593;[2003] FCR 1;[2003] 2 WLR 1174;[2003] UKHL 21" Feminist Legal Studies 12 (1) (2004):79-92.

Davis, Georgiann and Erin L Murphy, "Intersex Bodies as States of Exception: An Empirical Explanation for Unnecessary Surgical Modification" Feminist Formations 25(2) (2013): 129. 
Dietz, Chris. "Governing Legal Embodiment: On the Limits of Self-Declaration" Feminist Legal Studies 26 (2018): 185-204.

de Vries, Annelou et al, "Young Adult Psychological Outcome After Puberty Suppression and Gender Reassignment” Paediatrics 134(4) (2014): 696.

Duffy, Nick. "Prime Minister Theresa May challenged over deportation of LGBT asylum seekers", PinkNews, October 25, 2017. Accessed March 28, 2020, https://www.pinknews.co.uk/2017/10/25/prime-minister-theresa-may-challenged-overdeportation-of-lgbt-asylum-seekers/.

Dunne, Peter. "Ten years of gender recognition in the United Kingdom: still a "model for reform"?" Public Law Oct. (2015): 530-539.

Dunne, Peter. “Transgender Children and the Law" Family Law 47 (January) (2017): 123-124.

Dunne, Peter. "Towards Trans and Intersex Equality: Conflict or Complementarity?" in Jens Scherpe, Tobias Helms and Annatol Dutta, The Legal Status of Intersex Persons (Intersentia, 2018) 229.

Dunne, Peter and Jule Mulder, "Beyond the Binary: Towards a Third Sex Category in Germany?" German Law Journal 19(3) (2018): 627-648. 
Dunne, Peter and Marjolein van den Brink, Trans and Intersex Equality Rights in Europe: A Comparative Analysis (Luxembourg: Publications Office of the European Union, 2018).

Dunne, Peter. "Acknowledging or Erasing Intersex Experiences? Gender "Diversity" in German Law" Northern Ireland Legal Quarterly 70(1) (2019): 163-169.

Dunne, Peter and Stephen Clark, Comparative Legal Overview of Gender Recognition Laws across the Commonwealth (Equality and Justice Alliance, 2019).

Dustin, Moira. "Many Rivers to Cross: The Recognition of LGBTQI Asylum in the UK" International Journal of Refugee Law 30(1) (2018): 104-127.

Dustin, Moira and Nina Held. "In or Out: A Queer Intersectional Approach To 'Particular Social Group' Membership and Credibility in SOGI Asylum Claims in Germany and the UK" Genius 2 (2018): 74-87.

Ehrbar, Randall D et al, "Clinician Judgment in the Diagnosis of Gender Identity Disorder in Children" Journal of Sex and Marital Therapy 34(5) (2008): 385.

Faissin, Didier. “The Precarious Truth of Asylum” Public Culture 25(1) (2013): 39-63. Fausto-Sterling, Anne. Sexing the Body (Basic Books, 2008).

Fernandez, Bina. "Queer Border Crossers: Pragmatic Complicities, Indiscretions and Subversions" in Dianne Otto (ed) Queering International Law: Possibilities, Alliances, Complicities, Risks (Routledge, 2017):193-211, 211. 
Garland, Fae and Mitchell Travis, "Legislating Intersex Equality: Building the Resilience of Intersex People through Law" Legal Studies, 38(4) (2018): 587 - 606.

Garland, Jameson and Santa Slokenberga, "Protecting the rights of children with intersex conditions from non-consensual gender-conforming medical interventions: the view from Europe" Medical Law Review 27(3) (2019): 481.

“Gender Recognition Reform (Scotland) Bill: consultation” Scottish Government website, December 17, 2019. Accessed March 29, 2020, https:/www.gov.scot/publications/gender-recognition-reformscotland-bill-consultation-scottish-government/.

Gilmore, Stephen. "Bellinger v Bellinger - not quite between the ears and between the legs transsexualism and marriage in the Lords" Child and Family Law Quarterly 15(3) (2003): 295311.

Gonzalez-Salzberg, Damian A. "The Accepted Transsexual and the Absent Transgender: A Queer Reading of the Regulation of Sex/Gender by the European Court of Human Rights" American University International Law Review 29(4) (2013): 797.

Government Equalities Office. National LGBT Survey: Summary Report (June 2018). Accessed March 29 2020 , https://assets.publishing.service.gov.uk/government/uploads/system/uploads/attachment_data /file/722314/GEO-LGBT-Survey-Report.pdf 
Government Equalities Office. "Variations in Sex Characteristics Call For Evidence" Government Equalities Office website, January 17, 2019. Accessed March 29, 2020, https://www.gov.uk/government/consultations/variations-in-sex-characteristics-call-forevidence.

Grabham, Emily . "Governing Permanence: Trans Subjects, Time, And The Gender Recognition Act” Social \& Legal Studies 19(1): (2010): 107-126.

Greenberg, Julie. "Defining Male and Female: Intersexuality and the Collision between Law and Biology" Arizona Law Review 41(2) (1999): 265.

Hartley, Emma. "Why do so many teenage girls want to change gender?" Prospect, March 3, 2020. Accessed March 29, 2020, https://www.prospectmagazine.co.uk/magazine/tavistocktransgender-transition-teenage-girls-female-to-male.

Hird, Myra. "Gender's Nature: Intersexuality, Transsexualism and the 'Sex"/“Gender' Binary” Feminist Theory 1(3) (2000): 347.

Holzer, Lena. "Sexually Dimorphic Bodies: A Production of Birth Certificates" Australian Feminist Law Journal 45(1) (2019): 91-110.

House of Commons Select Committee on Women and Equalities, Transgender Equality (London: The Stationery Office Limited, 2016). 
ILGA-Europe, “Intersex” ILGA Europe website. Accessed March 29, 2020, https://www.ilgaeurope.org/what-we-do/our-advocacy-work/trans-and-intersex/intersex.

ILGA, "State Sponsored Homophobia: Global Legislation Overview Update" (December 2019). Accessed March 28, 2020 https://ilga.org/downloads/ILGA_World_State_Sponsored_Homophobia_report_global_legis lation_overview_update_December_2019.pdf.

Jens M Scherpe (ed), The Legal Status of Transsexual and Transgender Persons (Intersentia, 2015).

Johnson, Paul and Robert Vanderbeck, Law, Religion and Homosexuality (Routledge, 2014)

Jordan, Sharalyn. "Un/Convention(al) Refugees: Contextualizing the Accounts of Refugees Facing Homophobia or Transphobic Persecution" Refuge 26 (2011): 165-182.

Korkiamäki, Iina Sofia. "Legal Gender Recognition and (Lack of) Equality in the European Court of Human Rights" The Equal Rights Review 13 (2014): 20-50.

Loue, Sana. "Transsexualism in medicolegal limine: an examination and a proposal for change" Journal of Psychiatry and Law 24(1) (1996): 27.

Maine, Alexander. "The Hierarchy of Marriage and Civil Partnerships: Diversifying Relationship Recognition" in Frances Hamilton and Guido Noto La Diega (eds) Same-Sex Relationships, Law and Social Change (Routledge, 2020) 209. 
Millbank, Jenni. "Fear of Persecution or a Just a Queer Feeling?: Refugee Status and Sexual Orientation in Australia" Alternative Law Journal 20(6) (1995): 261.

Millbank, Jenni. "Imagining Otherness: Refugee Claims On The Basis Of Sexuality In Canada and Australia" Melbourne University Law Review 26(7) (2002): 144.

Millbank, Jenni. "Gender, Sex and Visibility in Refugee Claims on the Basis of Sexual Orientation” Georgetown Immigration Law Journal 18 (2003): 71.

Millbank, Jenni. “A Preoccupation with Perversion: The British Response to Sexual Orientation Refugee Claims, 1989-2003” Social \& Legal Studies 14(1) (2005): 115.

Millbank, Jenni. "The Ring of Truth: A Case Study of Credibility Assessment in Particular Social Group Refugee Determinations” International Journal of Refugee Law 21(1): (2009): 1.

Millbank, Jenni. "From Discretion to Disbelief: Recent Trends in Refugee Determinations on the Basis of Sexual Orientation in Australia and the United Kingdom" The International Journal of Human Rights 13(2-3) (2009): 391.

Mir, Saima. "I feel caught in the middle': queer Muslims on the LGBTQ lessons row”, The Guardian, March 27, 2019. Accessed March 28, 2020, https://www.theguardian.com/education/2019/mar/27/caught-in-middle-queer-muslimslgbtq-lessons-schools-protests. 
Norman, Julian. “'Shifting Sands' Six Legal Views on the Transgender Debate” The Guardian, $\begin{array}{lllll}\text { October } & \text { 2018. } & \text { Accessed 29, }\end{array}$ https://www.theguardian.com/society/2018/oct/19/gender-recognition-act-reforms-six-legalviews-transgender-debate.

Newbould, Mary. "When Parents Choose Gender” Medical Law Rev 24 (2016): 471.

Olson, Kristina R et al, "Mental Health of Transgender Children Who Are Supported in Their Identities" Paediatrics 137(3) (2016).

Olson, Kristina. 'Prepubescent Transgender Children: What We Know and What we Do Not Know' (2016) 55(3) Journal of the American Academy of Child and Adolescent Psychiatry 155.

"Parkfield Community School: Ofsted says LGBT lessons are 'appropriate"”, BBC News, March 2, 2019. Accessed March 28, 2020, https://www.bbc.co.uk/news/uk-englandbirmingham-47536752.

Parsons, Vic. "Trans kids are as sure of their gender as cis kids at a young age, according to science" Pink News, December 27, 2019. Accessed March 29, 2020, https://www.pinknews.co.uk/2019/12/27/transgender-children-study-gender-identity-cischildren-washington-university/.

Parveen, Nazia. "Birmingham school stops LGBT lessons after parents protest", The Guardian, March 4, 2019.

Accessed March 28 , 2020 , 
https://www.theguardian.com/education/2019/mar/04/birmingham-school-stops-lgbt-lessonsafter-parent-protests.

Parveen, Nazia. "Parents complain to Manchester schools about LGBT lessons", The Guardian, March 19, 2019. Accessed March 28, 2020, https://www.theguardian.com/education/2019/mar/19/fresh-complaints-about-lgbt-lessons-atgreater-manchester-primary-schools.

Puar, Jasbir. "Homonationalism as Assemblage: Viral Travels, Affective Sexualities" Jindal Global Law Review 4(2) (2013): 23.

"Public Statement by the Third International Intersex Forum" ILGA-Europe. Accessed March 29, 2020, https://www.ilga-europe.org/what-we-do/our-advocacy-work/trans-andintersex/intersex/events/3rd-international-intersex-forum.

Raj, Senthorun. "A/Effective Adjudications: Queer Refugees and the Law" Journal of Intercultural Studies 3(4) (2017) 453-468.

"Reform of the Gender Recognition Act 2004" UK Government website, July 3, 2018. Accessed March 29, 2020, https://www.gov.uk/government/consultations/reform-of-thegender-recognition-act-2004.

Rosenthal, Stephen. “Approach to the Patient: Transgender Youth: Endocrine Considerations" The Journal of Clinical Endocrinology and Metabolism 99(12) (2014): 4379 
Sanai, J Leyla. “The Danger of Letting Children Transition Too Early” The Spectator, May 13, 2019. Accessed March 29, 2020, https://www.spectator.co.uk/article/the-danger-of-lettingchildren-transition-gender-too-early.

Sandland, Ralph. "Feminism and the Gender Recognition Act 2004" Feminist Legal Studies 13(1) (2005): 43-66.

Scherpe, Jens M and Peter Dunne, "The Legal Recognition of Transsexual and Transgender Persons - Comparative Analysis and Recommendations" in Jens M Scherpe (ed), The Legal Status of Transsexual and Transgender Persons (Intersentia, 2015).

Sharpe, Alex. "Endless Sex: The Gender Recognition Act 2004 and the Persistence of a Legal Category" Feminist Legal Studies 15 (1) (2007): 57-84.

Sharpe, Alex . "Gender Recognition in the UK: A Great Leap Forward." Social \& Legal Studies 18 (2) (2009): 241-245.

Sharpe, Alex. "Will Gender Self-Declaration Undermine Women's Rights and Lead to an Increase in Harms?" Modern Law Review. Accessed March 24, 2020. https://doi.org/10.1111/1468-2230.12507.

Silverman, Michael. "Issues in Access to Healthcare by Transgender Individuals" Women's Rights Law Reporter 30(2) (2009): 347. 
Spade, Dean. “Resisting Medicine, Re/modelling Gender” Berkeley Women's Law Journal 18 (2003): 15 .

Spade, Dean. "Documenting Gender” Hastings L.J. 59 (2007): 731.

"Statement on Gender Affirmative Approach to Care from the Paediatric Endocrine Society Special Interest Group on Transgender Health". Accessed March 29, 2020, https://www.pedsendo.org/members/members_only/PDF/TG_SIG_Position\%20Statement_1 0_20_16.pdf

Stock, Kathleen. "Changing the concept of 'woman' will cause unintended harms" The Economist, July 6, 2018, accessed March 29, 2020, https://www.economist.com/openfuture/2018/07/06/changing-the-concept-of-woman-will-cause-unintended-harms.

Stock, Kathleen. "Why Self-Identification Should not Legally Make You a Woman" The Conversation, October 1, 2018. Accessed March 29, 2020, https://theconversation.com/whyself-identification-should-not-legally-make-you-a-woman-103372.

Stonewall UK. "School Report: The Experiences of Lesbian, Gay, Bi and Trans Pupils in Britain's Schools", Stonewall website, November 2017. Accessed March 28, 2020, https://www.stonewall.org.uk/system/files/the_school_report_2017.pdf.

Streuli, Jurg C. et al, "Shaping Parents: Impact of Contrasting Professional Counseling on Parents' Decision Making for Children with Disorders of Sex Development" Journal of Sexual Medical 10 (2013): 1953. 
Tannehill, Brynn. "The End of the Desistence Myth", Huffington Post, January 1 2016, accessed March 29, 2020, http:/www.huffingtonpost.com/brynn-tannehill/the-end-of-thedesistance_b_8903690.html.

Theilen, Jens T. "Depathologisation of Transgenderism and International Human Rights Law" Human Rights Law Review 14 (2014): 327-342.

Transgender Trend. "Transgender Trend Submission to the Gender Recognition Reform (Scotland) Bill Consultation", March 21, 2020. Accessed March 29, 2020, https://www.transgendertrend.com/transgender-trend-submission-gender-recognition-reformscotland-bill/.

Turner, Janice. "Cult of Gender Identity is Harming Children” The Sunday Times, September 21, 2019. Accessed March 29, 2020, https://www.thetimes.co.uk/article/cult-of-genderidentity-is-harming-children-pjvbkjzxq;

UK Home Office. "Experimental Statistics: Asylum Claims on the basis of sexual orientation" (August 2019), $\quad$ Accessed March 2020, https://www.gov.uk/government/publications/immigration-statistics-year-ending-june2019/experimental-statistics-asylum-claims-on-the-basis-of-sexual-orientation.

UKLGIG. "Missing the Mark: Decision Making on Lesbian, Gay, Bisexual, Trans, and Intersex Asylum Claims (September 2013). Accessed March 28, 2020, https://uklgig.org.uk/wp-content/uploads/2014/02/Missing-the-Mark.pdf; 
UKLGIG. Still Falling Short: The Standard of Home Office Decision-Making in Asylum Claims Based on Sexual Orientation and Gender Identity (UKLGIG, July 2018). Accessed March 28, 2020, https://uklgig.org.uk/wp-content/uploads/2018/07/Still-Falling-Short.pdf.

UKLGIG, "Submission to the Independent Chief Inspector of Borders and Immigration inspection of the Home Office's Presenting Officers' function" (January 2020). Accessed March 20, 2020, https://uklgig.org.uk/wp-content/uploads/2020/02/UKLGIG-submission-toICIBI-inspection-of-presenting-officers-Jan-2020-FINAL.pdf.

Valverde, Mariana. Chronotopes of Law: Jurisdiction, Scale and Governance (Abingdon and New York: Routledge, 2015).

Weber, Cynthia. Queer International Relations (Oxford University Press, 2016).

Weber, Frances. "On the creation of the UK's 'hostile environment"' Race \& Class 60(4) (2019): 76-87 